\title{
Social Organization and Economic Situation
}

This chapter supplies an overview of the socio-economic situation of the Baduy, which may make it easier to understand the situation in which they play their music. The Baduy have a long history. This oral history is reflected in their stories and song texts. It goes back to the Hindu kingdoms in West Java, that is, the period before the end of the 16th century. Some of the documented history can be found in the Old Sundanese manuscripts. The history in printed books and documents covers only two centuries. An important milestone is a document of around 1800, in which the sultan of Demak describes the borders of Kanékés village (see Appendix 1). As from 1822 Dutch and other European visitors reported in writing about the Baduy and mentioned that this community numbered a few hundred people. This number is said to have increased to about fifteen hundred in 1930 and to around twelve thousand in 2016. Since the 1970 s an increasing number of Baduy families migrated, as part of a governmental project or on their own initiative, mainly because of the shortage of farming land in Kanékés.

A few hamlets outside Kanékés (so-called dangka hamlets) have played an important role in the delineation of the Baduy community from the other groups in Banten. The Baduy leaders do not have jurisdiction in most of these hamlets, as they are located outside Kanékés. For several socio-political and religious reasons explained below the Baduy gradually abandoned most dang$k a$ hamlets since the 1940 ond returned to Kanékés. This did not help to solve the problems of a growing population in Kanékés and an increasing shortage of farming land. However, it seems that during the 2010 s the Baduy community started to more emphatically claim their rights on this dangka land, which 'belonged to their ancestors', but was not under their jurisdiction.

The population increase in Kanékés village is affecting ideas on the 'slash and burn' farming as well. This farming is prescribed by the ancestors, however, it requires more agricultural land than irrigated fields do. There have also been attempts to become more independent from agricultural activities. Over the last decennia selling products like woven cloths and home-made knives to tourists has become an increasingly important source of income. Such cultural tourism has been promoted by the Banten provincial government.

This chapter only presents some of the major socio-economic issues. More comprehensive information can be found in Van Tricht (1929), Geise (1952), Danasasmita and Djatisunda (1986) and Garna (1988). A good summary of the 
Baduy social organization can be found in Ekadjati (1995). The more recent books by Permana (2001), Erwinantu (2012) and Hasman and Reiss (2012) also offer basic introductions to the Baduy. The last two books include many photographs and Erwinantu's book contains interesting drawings that he made.

Danasasmita and Djatisunda (1986) compare the present Baduy ascetic lifestyle to its description in three Old Sundanese manuscripts for the religious mandala communities. ${ }^{1}$ Geise (1952) and Garna (1988) offer anthropological approaches in which the focus is on agriculture. They also explain the kinship system, and the cosmology and the rice rituals during the different seasons of the agricultural year. Suryani's study ([2020]) supplies valuable information on the attempts to converse the Baduy and people from Baduy descent to Islam or Christianity from 1977-2017.

Section 2.1 below summarizes the literature on Baduy social organization. Over the last few decades the tasks of the secular leaders, like the village head and the 'group of twelve leaders' (pajaroan), seem to have increased, as compared to the tasks of the spiritual leaders. The shortage of land for agriculture and religion are addressed in Sections 2.2 and 2.3. Section 2.4 discusses the relation between the Baduy and the Indonesian authorities, and the promoted cultural tourism since the 200os. Section 2.5 is about the role of a few nongovernmental organisations that have been active in matters concerning the Baduy since the 1980s. Sections 2.6 and 2.7 look at some economic aspects of Baduy life, other than agriculture. This includes the weaving of cloths and the making of knives for their own use, but also increasingly for tourists.

\subsection{Socio-Political Organization and Major Spiritual and Secular Officials}

The Baduy have an organizational structure that deals with both spiritual and secular matters. On the one hand we find the rituals concerning the Baduy religion (Sunda wiwitan) and customary law (pikukuh, Indonesian: adat) as handed down by the ancestors (karuhun), on the other issues concerning daily life and the interactions with the outside world. Since about 1800 - or possibly earlier - the colonial and Indonesian governments allowed the Baduy a large amount of autonomy within Kanékés village. Being protected by the secular rulers they could live there as ascetics.

1 These manuscripts are: Amanat dari Galunggung, Sanghyang Siksakanda Ng Karesian and Carita Parahiyangan. 
The spiritual centre of the Baduy area is the Inner Baduy area, tangtu, with the three hamlets (tangtu tilu) Cikeusik, Cikartawana and Cibéo, and holy places like Sasaka Pusaka Buana, Sasaka Parahiang and the sacred forest. The size of the Inner Baduy area is almost half the size of Kanékés (see maps in Figures 2 and 13). The greater part of this Inner Baduy area is 'forbidden land' (taneuh larangan), which, among other things, means that it is not available for agriculture. The number of Inner Baduy living in this area constitutes about one-tenth (1200 people) of the Baduy community. The Outer Baduy, living to the west, north and east of the Inner Baduy area are often described as the ones who protect the sanctuaries and the Inner Baduy way of living from the outside world. One of the Baduy leaders, Ayah Mursid from Cibéo, described the Outer Baduy as a kind of 'filter' (penapis), protecting the Inner Baduy against the temptations from outside Kanékés (Erwinantu 2012: 36).

The sanctuary Sasaka Pusaka Buana (also called Pada Ageung or Arca Domas) is considered to be the place of origin of the world: the place where the seven sons of the highest god, Batara Tunggal, came down to earth. This sacred place lies near the source of the Ciujung River, in bird-flight about $2 \mathrm{~km}$ southeast of Cikeusik (see Figures 2 and 29). The spiritual leader (puun) of Cikeusik is responsible for keeping this heritage (sasaka) in good order (Danasasmita and Djatisunda 1986: 24-25; Garna 1988: 280, 294; Ekadjati 1995: 69). The exact position of Sasaka Pusaka Buana is kept secret and it is thought that it was only visited by a few people from outside.

Another sanctuary, Sasaka Parahiang (also called Mandala Parahiang or Sasaka Domas), lies at the source of the Ciparahiang River near Cibéo: see map in Figure 2. This is considered to be the place of origin of the Baduy community: it is the place that was first visited by Batara Cikal (literally: the 'god eldest one'), the eldest son of the highest god Batara Tunggal. Batara Cikal is considered to be the founder of Kanékés and ancestor of the puun. It is believed that Sasaka Parahiang is also the place where the souls of the deceased Baduy will eventually go: back to their origin. The spiritual leader (puun) of Cibéo is responsible for keeping this heritage in good order (Danasasmita and Djatisunda 1986: 25-26, 72; Ekadjati 1995: 69-70, 91).

In the past the Baduy area was larger than just Kanékés and it included seven so called dangka hamlets outside Kanékés, where Baduy claim some communal land and where they lived together with non-Baduy people, mostly Muslim Sundanese. These dangka hamlets lie north of Kanékés and seem to have served as a system of keeping outside influences away from the Inner and Outer Baduy areas (Van Tricht 1929: 71-2; Garna 1988: 140). There also have always been two dangka hamlets inside the boundaries of present-day Kanékés: Kaduketug (Gedé) and Cihulu. The dangka hamlets also were, and 
still are, used as places to which Inner Baduy are temporarily banned, when they are found guilty of breaking the Baduy customary rules. ${ }^{2}$ Depending on the severity of the breach of rules, Inner Baduy may be punished by the village authorities, or sent to a jaro dangka, or exiled. Exile means that the spiritual leaders no longer recognize them as belonging to the Baduy community. This may also happen to Outer Baduy. In Section 2.2 I will come back to the important role of the dangka hamlets for understanding the Baduy policies as regards other groups in Banten.

The Baduy have had a great deal of autonomy in organizing village Kanékés within the Dutch Indies and Indonesian bureaucratic system. The three Inner Baduy hamlets Cikeusik, Cikartawana and Cibéo each have a spiritual leader (puun; with honorific title: girang puun), a hamlet head (jaro tangtu) and a council of elders (baresan). In Cikeusik and Cibéo the puun is assisted by a seurat (with honorific title: girang seurat). The main tasks of the spiritual leaders, in particular the three puun, has been: (1) to look after and protect the Sasaka Pusaka Buana sacred place near Cikeusik; (2) to look after and protect the Sasaka Parahiang sacred place near Cibéo; (3) to advise the secular rulers in the world about how to rule over their subjects; (4) to live an ascetic life (see Danasasmita and Djatisunda 1986: 24-36; Garna 1988: 294).

Each Outer Baduy hamlet has its head (kolot lembur). Nine jaro dangka, who are all Outer Baduy, but of Inner Baduy descent (the $\mathrm{kaum}$ dalem/kaum daleum, Van Tricht 1929: 72-74) assist the Inner Baduy leaders in enforcing Baduy customary law. These jaro dangka used to live in the nine dangka hamlets, of which seven were outside and two inside Kanékés; see map in Figure 13. For several reasons to be discussed below, currently most (all?) of the jaro dangka live in a hamlet in Kanékés, although their dangka region outside Kanékés is still claimed as Baduy land.

The jaro tanggungan duabelas (- duawelas, tanggungan jaro duabelas; shorter: jaro duabelas) is an Outer Baduy, who leads the group of twelve jaro consisting of three jaro tangtu and nine jaro dangka. Although the three puun take the formal decisions, this group of twelve jaro (pajaroan) has much power in decision making processes and the practical implementations (see also Geise 1952: 23-24, 83-84; Garna 1988: 129-132; Bakels and Boevink 1988: 88). It seems that for the last fifty years or so the power of this group of leaders has

2 Erwinantu (2012: 37) quoted Ayah Mursid from Cibéo as saying that for serious offences against Baduy customary law the dangka hamlets were 'adat prisons'. Here the offenders were reformed and instructed by the adat elders of that hamlet. See also Pleyte (1912: 263, 266) and Van Tricht (1929: 72): in the 'tale about the origin of Kanékés' the hamlet Nangkabenkung is mentioned as a place of exile. 
increased, as compared to the power of the spiritual leaders (puun et al.). This needs more investigation.

The tangkesan is a seer (nujum), astrologer and healer, who has two assistants. These three seers are advisors to the three puun. The tangkesan lives in an official residence in the Outer Baduy area in one of the hamlets Kaduketer, Cicatang or Cikopéng and his main task is to look after the spiritual well-being of mainly the Outer Baduy (Garna 1988: 374-375; Geise 1952: 24). The tangkesan is also the major forecaster and with the three puun he is the only one involved in determining the Baduy calendar (Van Tricht 1929: 95; Danasasmita and Djatisunda 1986: 22; Garna 1988: 255).

The jaro pamaréntah (or jaro gubernemen) is the secular head of Kanékés village. He is an Outer Baduy who mediates between the spiritual leaders (puun and others) and the Indonesian authorities and therefore he frequently meets with the sub district head (camat) of Leuwidamar, district civil servants, health servants and other non-Baduy officials. The secular village head is not chosen by general elections, like elsewhere in present-day Indonesia. The three puun nominate someone to the government, and this nomination is generally accepted. Since 1992 the secular village head has had an official residence in Kaduketug 1 (Kaduketug Jaro) near Cibolégér. Nowadays the secular village head is paid for expenses related to his job (like travel expenses) by the Indonesian authorities. He is assisted by a non-Baduy village secretary (carik) and his staff for the administrative work. Since about 2010 the carik heads a small office in Cibolégér, just outside Kanékés and about a hundred metres from the official residence of the secular village head (Figures 10 and 11). Further, the secular village head is assisted in his work by the pangiwa (or panggiwa) the heads of administrative units (RW) and the heads of the hamlets $((k o)$ kolot lembur), that is, the equivalent of those responsible for the smaller administrative household units (RT) in the Indonesian system; see Appendix 1, in particular Tables 29 and 30 .

Like the power of the group of twelve pajaroan leaders, the power of the secular village head seems to have increased during the long office term of jaro Daénah (1997-2015). ${ }^{3}$ Until a few years ago the secular village head did not receive a salary from the Indonesian authorities, although other village heads in Indonesia did (Van Zanten 2004: 129-130). With the increasing grip

3 Jaro Daénah left office because he suffered from diabetes; he died 23 March 2019. In 2016 he still seemed to play a very important role behind the scene: his house was about $15 \mathrm{~m}$ from the official house of the new secular village head Saijah. According to Baduy standards Daénah was rich; he owned a lot of land (more than 100 ha, one informed Baduy said), mainly outside Kanékés and he owned his own keromong set of instruments. 


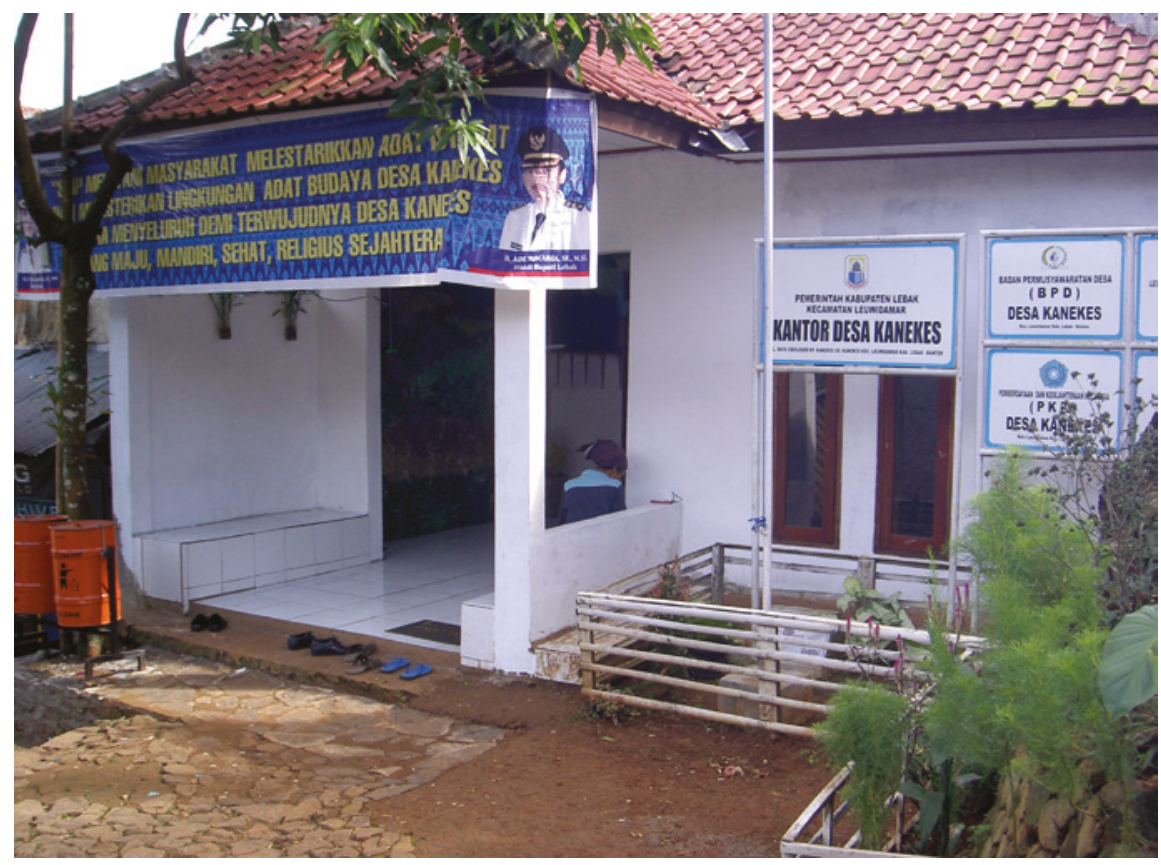

FIGURE 10 Office of the Kanékés secretariat in Cibolégér, about 10om from the residential house of the secular village head in Kanékés. 21 July 2016

of the Indonesian authorities on the Baduy community, it may be that this has changed already or that it will change soon. This used to be the same for the village secretary (carik). The long-time carik Ukang Sukarna (1970-1989 and 1992-2007) was never paid for his job by the Indonesian authorities. However, this changed in 2007, when Sapin became the first secretary to the secular village head who was paid for by the Indonesian authorities and became an official civil servant in the Indonesian administrative system. In 2016 Sapin was replaced by the new secretary Arman, who had been part of the secretarial team before. In 1989 Ukang Sukarna had asked to be replaced as village secretary, because that post involved a lot of work. From 1989-1992 he was replaced by Husein from Cibolégér. As the Baduy leaders were not satisfied with Husein, Ukang was asked to come back as village secretary, from 1992-2007 assisted by Sapin. Whereas before Ukang all secretarial work was done by one secretary, under Sapin the secretariat of village Kanékés expanded to eleven people in 2016.

Much work of the secular village head is concerned with the safety of Kanékés and disputes between Baduy and non-Baduy about land issues. Religion is another important issue to be discussed with the Indonesian authorities: see 


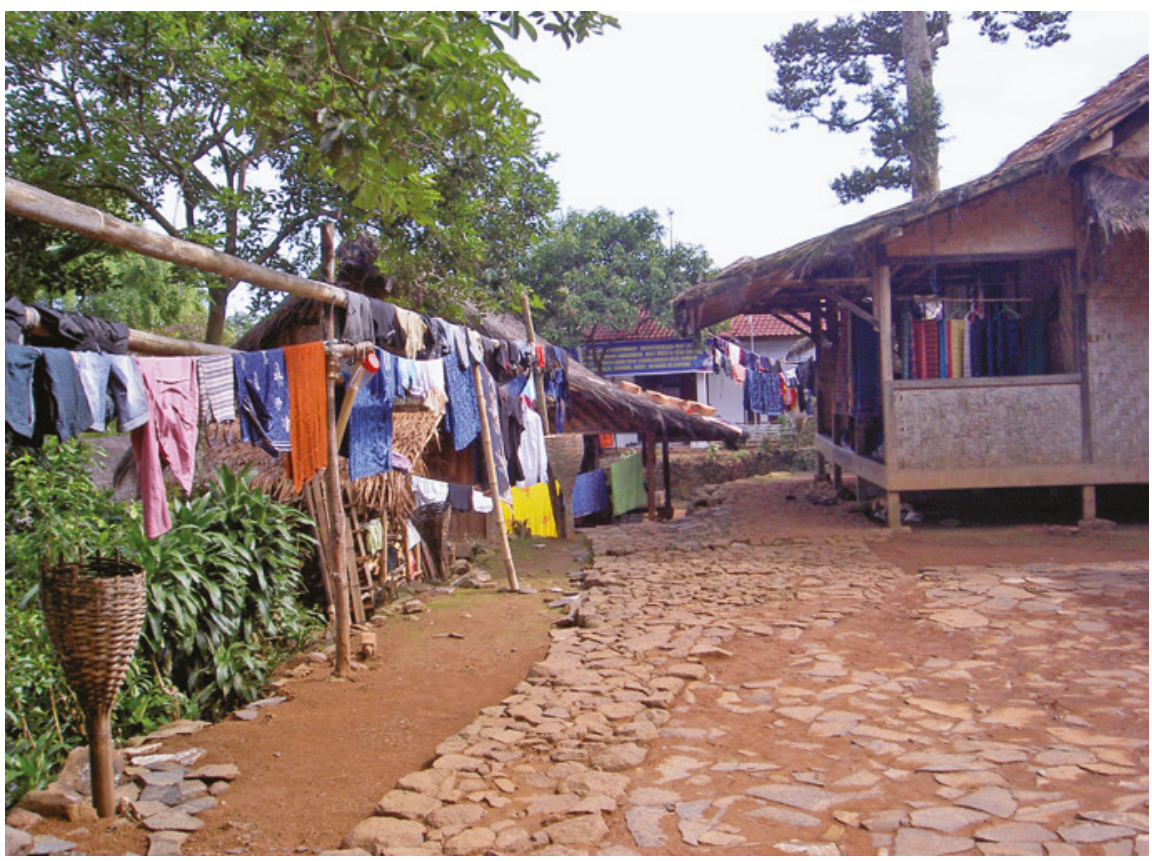

FIGURE 11 Yard in front of the secular village head's house, newly paved for the expected visit of president Joko Widodo; the centre back shows the white building of the Kanékés secretariat in Cibolégér. Kaduketug 1, 16 July 2016.

Section 2.3. Further, the secular village head represents the Baduy to official visitors (Figure 12). Currently he is also very much involved in organizing the individuals and groups of (mainly Indonesian) tourists who want to visit the Inner Baduy area (Van Zanten 2004: 145-147; see also Figure 6). On 5 July 2016 the secular village head Saijah told that he is now supposed to charge each visitor according to which place of Kanékés s/he wants to visit and for how long. From this money he should pay tourist taxes to the local government and that amounted to 8 million Rupiah per year (ca. $€ 552$, us \$ 6o8). Saijah also has plans for building accommodation for tourists just outside Kanékés, near the secretariat's office in Cibolégér. He would like to entertain the guests there with Baduy music and dance and sell Baduy products like woven cloths and knives (A2016-1: 26).

The first secular village head seems to have been Tarpi, who was mentioned by Koorders in his report about his visit to the Inner Baduy in 1864. Before the official job of jaro pamaréntah/jaro gubernemén was created, there was the jaro warega/wrega, leading activities outside Kanékés, like the séba (see below). In current practice the jaro warega seems to be the elder person under the jaro 


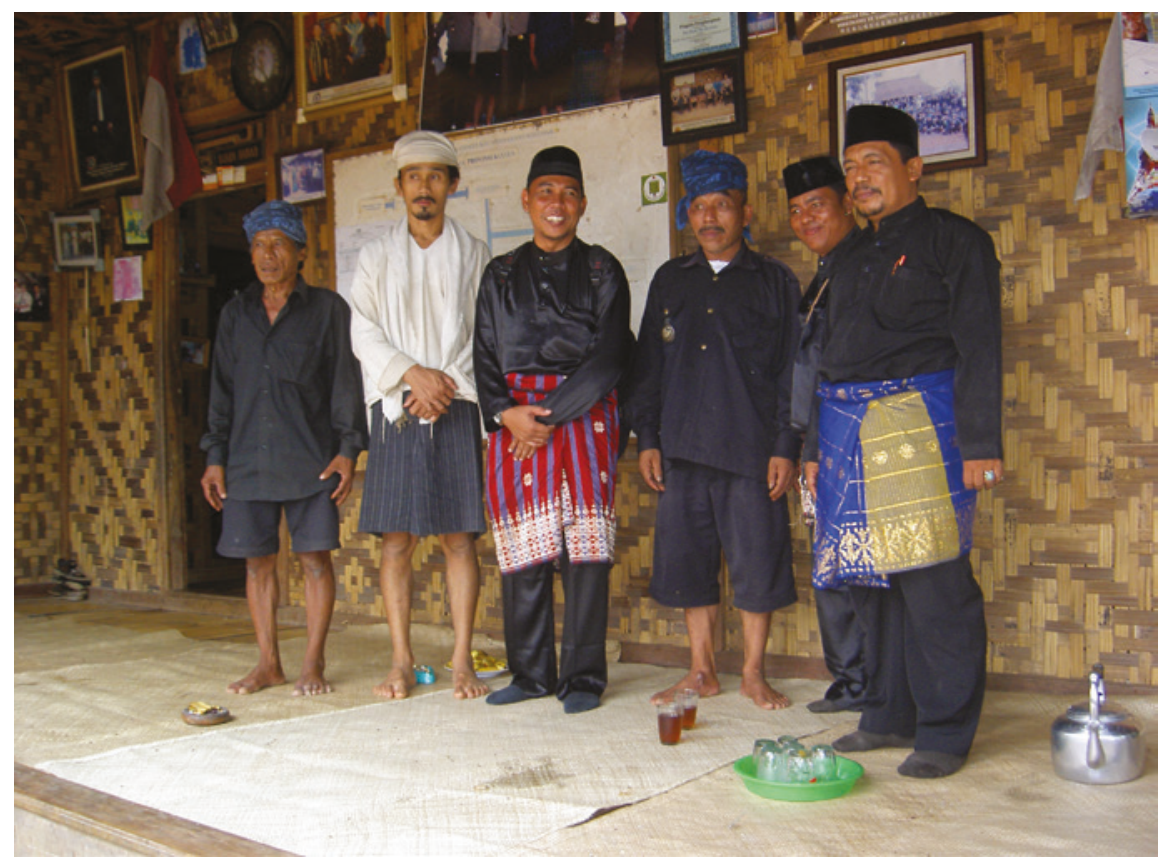

FIGURE 12 Baduy officials with visiting representatives of an indigenous community of Riau at the official residence of the secular village head in Kaduketug 1. Second from left is spokesman Mursid with Inner Baduy clothing and fourth from left is Daénah the secular village head, 12 December 2013

dangka (Danasasmita and Djatisunda 1986: 21). From Koorders' description, it seems that the first non-Baduy village secretary (carik) was Tayun. Tayun was born in Kanékés but later expelled and thus became an outsider (Meinsma 1869: 327; see also Section 3.2). The jaro pamaréntah became also the one who punishes Outer Baduy when they have breached the rules. Geise (1952: 86-87) mentions that these punishments were sometimes physical and severe.

The positions of puun, jaro tangtu and some other high posts are hereditary, but not the position of the secular village head (jaro pamaréntah; always an Outer Baduy), the heads of hamlets (kokolot or RT) and the heads of a group of hamlets (RW). According to Danasasmita and Djatisunda (1986: 66) such official positions, hereditary or not, are only for married men who already have a child. After the appointment, an official rarely stays in office during his whole life. One reason may be that he becomes ill and asks to be relieved from office, like secular village head Daénah, who stepped down in 2015 because of diabetes. Another reason may be that the puun and other officials may not be happy with the way a particular official carries out his duties and he may then be 
removed from office. Also, an official may himself ask for resignation because he becomes (too) old, or he may not like the responsibility of his office. Most village heads since 1945 were about five years in office, although some had two periods in office, like Samin (1966-1968? and 1976-1981).

The Baduy are monogamous and the major officials (puun, jaro, girang seurat, tangkesan) will have to step down when their wife dies. Geise (1952: 67-68) wrote that this rule is 'quite understandable' as regards the puun and his wife when we look at the 'functions they have to fulfil as married couple during the big feasts', and this 'probably also holds for the girang seurat and kokolot, whose wives also have a task at these feasts'. In her book on gender equality in the Baduy world Permana (2001: 73) confirms Geise's conclusion and adds that 'Women (wives) are considered to have stabilizing and dynamic influences on the leaders of the group' (see also Section 5.6 below). In current practice it is customary that a Baduy leader who stepped down from office will keep the title belonging to his former official position (jaro, girang puun, (ko)kolot, etcetera).

See further information on the social organization, for instance, in Geise (1952: 22-31) or Garna (1987: 87-90).

\subsection{Dangka Hamlets and Their Role in the Delineation of Baduy Culture}

The role of the nine dangka hamlets, seven of which are lying outside Kanékés village, needs to be studied when we want to understand Baduy politics in relation to the outside world. Unfortunately the information on the dangka hamlets is not clear and in many cases conflicting. It seems that Van Hoëvell (1845: 361$)$ was the first one to use the word 'dangka' in print. This happened in the construction jelma dangka (dangka people), by which he meant the group of the Baduy, distinguishing them from the Muslim Sundanese living around them. Zoetmulder (1982: 363) gives for the Old Javanese word dangka: 'prob[ably] a hermit's abode or other kind of building with religious purpose, sanctuary?'.

However, as mentioned in Section 2.1 the dangka hamlets are already mentioned as places of exile in the stories about the origin of the Baduy community (Pleyte 1912: 263, 266, Van Tricht 1929: 72). Also Spanoghe (1838: 297) mentioned some hamlets used as 'places of exile' for Inner Baduy in his field notes dating from 1823. He gave the names of three hamlets for the 'Badoewienen' (Inner Baduy) and seven hamlets for the 'Orang-Kaloearan' (Outer Baduy). The latter hamlets are clearly the present-day dangka hamlets. Jacobs and Meijer (1891: 46) listed seven dangka hamlets of which six still exist on more or less the same place; one may have obtained a new name. 


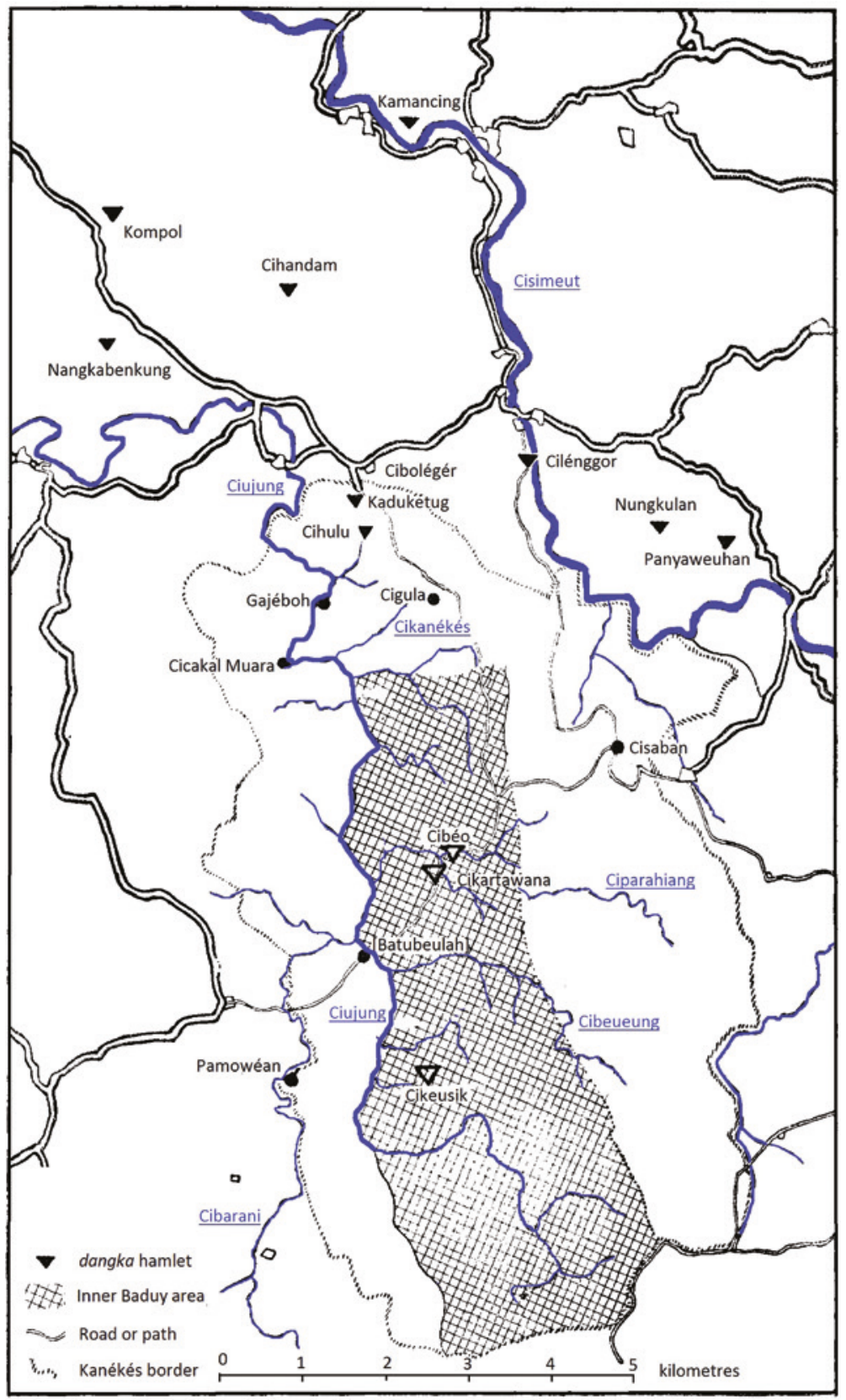

FIGURE 13 Map of the seven dangka hamlets outside and the two dangka hamlets inside Kanékés $(\boldsymbol{\nabla})$, based on Van Tricht (1929: after p. 72). '[Batubeulah]' indicates the position of this hamlet in 1929 (compare Figure 2). 
This section will only give a short account on the position of the dangka hamlets in the Baduy society. Starting point will be the information given by Van Tricht (1929) and Geise (1952), who supply a fuller account of the situation than the earlier authors. Van Tricht listed nine dangka hamlets in 1929, two inside and seven outside Kanékés village: see Figure 13, and Table 1 below. The dangka hamlets outside Kanékés are - in bird-flight - all within a radius of 5 $\mathrm{km}$ from Kaduketug Gedé and north of Kanékés village. The dangka hamlets are located in the 'non-sacred' northern direction to which individual Baduy are banned after severely trespassing the Baduy rules. The south is the sacred direction, which is also more difficult to access. In the three tangtu hamlets of the Inner Baduy the house of each puun (spiritual leader) is positioned in the most southern part. See further Garna (1984; 1988: 351-355) and Wessing (2003) on this north-south orientation. See also Section 6.4 on the position of the pantun performer at circumcisions.

Since about 1940 the Baduy started to abandon the dangka hamlets outside Kanékés and moved to hamlets inside Kanékés. As the number of people belonging to the Baduy community in Kanékés gradually increased over time and the available agricultural land per family and per person decreased, one would have expected the reverse: a resettlement from hamlets inside Kanékés to dangka hamlets outside Kanékés. Probably in the 1940s and 1950s the Second World War and the subsequent 'time of political chaos and revolutionary war' (Horikoshi 1975: 59; see also Van Dijk 1981: 102-108) influenced Baduy in the dangka hamlets to return to the safer place Kanékés. It is also possible that the Darul Islam movement in West Java (1948-1962) was not very tolerant towards the Baduy religion and living in a dangka village, surrounded by Muslims, became more problematic than before. Moreover, the Baduy may (again) have been cautioned by the attitude of the leader of the Darul Islam movement, Kartosuwirjo. In a letter ('secret note number 2', nota rahasia kedua) of ${ }_{17}$ February ${ }_{1951}$ Kartosuwirjo wrote to Sukarno, the first Indonesian president, that he 'was convinced that a third World War was imminent and that such a war would involve a struggle between the communist and non-communists blocks' (Van Dijk 1981: 118-119). In his letter Kartosuwirjo subsequently called these two blocks Komunisme and Islamisme (Boland 1971: 253).

In the literature I found little information on the Baduy in the $1945^{-1970}$ period, and in particular not about the influence of the Darul Islam movement on their situation. Most publications that mention the Darul Islam movement of Kartosuwirjo (like Boland 1971, Horikoshi 1975, Van Dijk 1981, and Ekadjati 2003) concentrated on events in the central and eastern part of the Priangan and not the region around Kanékés. However, it is clear that this was a very difficult period for people living in all the rural areas of West 
TABLE 1 Ritual names of dangka hamlets, location of the dangka land, residence of the jaro dangka, and connection of the dangka hamlet to an Inner Baduy hamlet

The sign + means that the jaro dangka of this hamlet is responsible for taking care of the people expelled from an Inner Baduy hamlet, because they committed an offence according to the Baduy rules (pikukuh); see Geise (1952: 9o) and Garna (1988: 140). ${ }^{\text {a }}$

\begin{tabular}{|c|c|c|c|}
\hline $\begin{array}{l}\text { Ritual name of } \\
\text { dangka land/hamlet } \\
\text { (Geise 1952: 30; } \\
\text { Garna 1988:232) }\end{array}$ & $\begin{array}{l}\text { Location of the dangka land } \\
\text { (tanah buyut) }\end{array}$ & $\begin{array}{l}\text { Residence of jaro dangka } \\
\text { in July } 2016\end{array}$ & $\begin{array}{l}\text { Related to Inner } \\
\text { Baduy hamlet (Van } \\
\text { Tricht 1929: 74; } \\
\text { Geise 1952: 30) }\end{array}$ \\
\hline & Outside Kanékés (7) & & \\
\hline Padawaras & $\begin{array}{l}\text { + Cibengkung/Nangkabenkung } \\
\text { (Cibungur village) }\end{array}$ & Inside Kanékés & \multirow{3}{*}{$\begin{array}{l}\text { Cikeusik (Pada } \\
\text { Ageung) }\end{array}$} \\
\hline Garukgak & Kompol (Cisimeut village) & Kompol & \\
\hline $\begin{array}{l}\text { Werega or Sanghyang } \\
\text { Panunggulan }\end{array}$ & Kamancing (Cisimeut village) & $\begin{array}{l}\text { Kamancing; Batara } \\
\text { according to Pasya } 2008^{\mathrm{b}}\end{array}$ & \\
\hline Inggung & $\begin{array}{l}\text { + Panyaweuyan } \\
\text { (Karangcombong village, } \\
\text { Muncang district) }\end{array}$ & Cisaban (Pasya 20o8) & \multirow{3}{*}{$\begin{array}{l}\text { Cikartawana } \\
\text { (Kadu Kujang) }\end{array}$} \\
\hline Sindangnyair & $\begin{array}{l}\text { Nungkulan (Karangcombong } \\
\text { village, Muncang district) }\end{array}$ & Inside Kanékés & \\
\hline Sanghyang Asuh & $\begin{array}{l}\text { Cilénggor/Garéhong (Cisimeut } \\
\text { village) }\end{array}$ & Inside Kanékés & \\
\hline \multirow[t]{2}{*}{ Sirahdayeuh } & Cihandam (Cisimeut village) & Kaduketug Gedé, Kanékés & \multirow{4}{*}{ Cibéo (Parahiang) } \\
\hline & inside Kanékés (2) & & \\
\hline Cipatih (Cipatik) & + Cihulu, Kanékés & Cihulu, Kanékés & \\
\hline $\begin{array}{l}\text { Singalayang (= } \\
\text { Carungeun?) }\end{array}$ & Kaduketug Gedé, Kanékés & $\begin{array}{l}\text { Kaduketug 1/- Jaro, } \\
\text { Kanékés (? since 2016) }\end{array}$ & \\
\hline
\end{tabular}

a Van Tricht (1929: 74) mentions that Inner Baduy from Cikartawana will not be banned to Panyaweuyan, but to Cilénggor/Garéhong. Outer Baduy may also be banned to a dangka hamlet, as Geise already reported (Geise 1952: 88-100). 'Banned to a dangka hamlet' actually means: banned to the hamlet where the responsible jaro dangka lives. Currently seven of the nine jaro dangka live in Kanékés.

b See article 'Implikasi modernisasi pada masyarakat Baduy' of 27 August 2008 by Gurniwan Kamil Pasya on Internet https://geocorida.blogspot.nl/2008/o8/perubahan-budaya-masyarakat-baduy-2.html [last access 21 April 2019.] 
Java. Boland (1971: 61-62) mentioned that in the early 1950s 'the Darul Islam in West Java seemed more and more to degenerate into terrorizing and plundering gangs which could not return to normal life in society'. The effects of the Darul Islam movement on the position of the Baduy needs further investigation. ${ }^{4}$

In the 1970s the Indonesian authorities tried to solve the land shortage of the Baduy by stimulating resettlement to areas outside Kanékés and they set up resettlement schemes. ${ }^{5}$ The first resettlement hamlet was at Cipangembar, about $15 \mathrm{~km}$ north of Kaduketug, where each migrant received a house and one hectare of agricultural land in 1978 (see below). The resettlement projects of the second half of the 1970s and later were no great success and also Baduy living in the dangka hamlets kept returning to Kanékés. In the period after 1978 the denigratory attitude of the Indonesian authorities did not support sustainable development: 'the government considered the "tribal ethnic groups" of lower social consciousness and level of responsibility, and less civilised'. Moreover, the responsible authorities put pressure on the resettled Baduy to become Muslim; that was considered the best solution for the migrants and stability of the social situation (Van Zanten 2004: 130-141).

In 1999 the secular village head Daénah had expressed critical views about the government's programmes for Baduy resettlement: 'We never asked for hamlets and new houses, but we get them all the time. Because there is already a project, the building has to continue'. (Van Zanten 2004: 132). This attitude towards resettlement seems to have changed. During the last years the policies of the Baduy leaders as regards the dangka settlements seem to have been changing as well. Mainly because of land shortage in Kanékés and the more limited possibilities to find land outside Kanékés, secular village head Saijah and other Baduy leaders encourage Baduy people to move back again to the land in the abandoned dangka hamlets, but until now without much success, jaro Saijah told me in July 2016 (Van Zanten 2017: 95).

4 Also in some recent literature about the $1945^{-1950}$ Independence war, I did not find any reference to the Baduy or the Lebak region. In particular, Rémy Limpach's well-documented book on Dutch war crimes in this period (Limpach 2016) does not contain any such information. Also Oostindie (2015) lacks information on this.

5 In earlier publications I used the word 'transmigration' programmes for these Baduy resettling schemes. Gerard Persoon (personal communication, February 2020) reminded me that it would be better to use 'settlement' or 'resettlement' for the Baduy transmigration hamlets in West Java (Indonesian: pemukiman/pemukiman kembali; Sundanese: pamukiman). In Indonesia and in anthropological literature about Indonesia the word 'transmigration' has been reserved for a resettlement from Java, Bali, Madura to the other islands in Indonesia, like Sumatra and Papua. 
Although currently Baduy inhabitants have left most of the dangka hamlets, this does not mean that the Baduy have also given up on their rights to use the ancestral dangka lands. The Baduy know exactly where the borders of these ancestral lands are. Garna (1988: 414-5) listed the boundaries of the seven dangka hamlets outside Kanékés, except for Panyaweuyan, in May 1970. This Baduy claim on dangka land is in conflict with Indonesian law: although the Baduy have been given collective land rights (hak ulayat) in the Kanékés area, this does not hold for the dangka lands that are under the jurisdiction of the villages to which they belong. For instance, according to the Baduy the jaro dangka Padawaras (see Table 1) is responsible for the dangka lands (and possible Baduy inhabitants) in Cibengkung/Nangkabenkung. This hamlet is located in village Cibungur, although nowadays its jaro dangka is living in a hamlet of Kanékés village. We have to distinguish between the location of the dangka lands and the residence of its Baduy head (jaro dangka).

The process of abandoning the dangka hamlets has been reported already since $195^{2}$ and sometimes reasons were given. Geise (1952: 23) reports that there was only one Baduy family living in Kamancing: the family of the head of the dangka hamlet (jaro dangka). Garna $(1988: 138,224)$ mentions that in the years 1945-1947 the jaro dangka of the four hamlets Cibengkung (dangka Padawaras), Kompol (dangka Garukgak), Cihandam (dangka Sirahdayeuh) and Kamancing (dangka Werega/Sanghyang Panunggulan) moved their seats to inside Kanékés because of problems concerning land and religion; the first three dangka heads all moved to Kaduketug Gedé.

Persoon (1994: 331) reported that 'some dangka hamlets have now been moved to Kanékés village, because of the great pressure by the surrounding farmers. ${ }^{6}$ The Baduy have always been fairly successful in an economic way: they invest in land, gold and other precious objects, and live a modest life. In the dangka hamlets this frequently led to jealousy and frictions between them and their Muslim neighbours. Together with the religious frictions this seems to be an important reason for the retreat of the Baduy inhabitants and heads of the dangka hamlets to Kanékés. For instance, in July 2016 the pantun storyteller Anirah told me that

6 It would have been more precise so say that most inhabitants and the jaro dangka of some hamlets had moved to Kanékés and left the dangka land that the Baduy still consider to be their communal property. That is the formulation used by Persoon on page 322 : ' $\ldots$ the dangka functions and inhabitants of Kamancing and Cihandam were moved to Kaduketug.' The people moved and, according to the Baduy, the dangka land remained where it had been before. 
1. Around 1995 the Baduy living in Cihandam (dangka Sirahdayeuh) did not want a mosque near their houses and that was the reason that they were chased away from the dangka hamlet in Cihandam.

2. In Garéhong (dangka Panyaweuyan) a non-Baduy stole rice from a Baduy rice barn (leuit). This thief was killed. That was the reason that the Baduy inhabitants had to leave this place: they cannot live in a place where a human being has been killed (Anirah, A2016-1: 64.)

Dangka Cipatih/Cipatik was always located in Cihulu, Kanékés. Dangka Singalayang is the other dangka hamlet in Kanékés village and it used to be in Kaduketug Gedé. In July 2016 I saw activities of building the official house for the (former?) jaro dangka Singalayang near the official house of the secular village head. This possibly means that the jaro dangka Singalayang moved to Kaduketug 1, the seat of the secular village head in 2016.

Whereas since $195^{\circ}$ five of the seven dangka hamlets outside Kanékés have (almost) been abandoned, this does not mean that all Baduy living there moved to Kanékés. For instance, in 1976 there were Baduy living in the dangka hamlets Kompol and Babakan Kompol, Cisimeut village: I then recorded music in the house of Péi (Sapéi) in Babakan Kompol. Since 2000 it seems that most Baduy living on dangka lands are based in Kompol: for 2003 I estimated their number to be around 400 (Van Zanten 2004: 12627), and according to my information that is still more or less the number in $2016 .{ }^{7}$ Nevertheless, also the abandoned dangka hamlets outside Kanékés are still considered to be very much related to the Baduy world and history and claimed as communal Baduy 'property'. It is sacred land (tanah buyut), according to one of Geise's informants (Geise 1952: 30, 187). However, this dangka land and also the land that Baduy farmers bought outside Kanékés does not fall under the Indonesian law for collective land rights (hak ulayat), like Kanékés village itself. ${ }^{8}$

The history of the dangka hamlets still needs to be studied properly, because it may shed more light on Baduy policies towards the outside world. I shall not go into more detail here, as the literature and my own data are not very consistent about the dangka hamlets and that includes their names. Geise (1952: 30) already pointed out that, although the Baduy speak about 'the seven jaro dangka', there are nine: two of them live inside 'the holy territory of the Baduy community', that is, in Kaduketug and Cihulu.

7 Kurnia and Sihabudin (2010: 75 ) report that there are 423 people living in Kompol at the end of the year 2008 and that the dangka land there available for Baduy is about 25 hectare.

8 Kabupaten Lebak 2001. See also information by Mr. Bedawi, an official from Tangerang, whom I met unofficially on 8 July 2016 in Kaduketug Jaro (A2016-1: $35^{-36}$ ). 
In December 2013 the village secretary, carik Sapin, gave me the organizational scheme he had made and which included 7 dangka hamlets (instead of 9): Carungeun, Garéhong, Nungkulan, Cibengkung, Cihandam, Panyaweuyan, Cihulu. These were also listed at the secretarial office and the official house of the jaro pamaréntah in July 2016. Surprisingly, Sapin did not list Kompol and Kamancing in this scheme. Sapin and the village head Saijah explained that this was, because Kompol and Kamancing fell under the jurisdiction of Cisimeut village, and not of Kanékés. I take this to mean also that in 2016 only the two jaro dangka of Kompol and Kamancing had their official residence outside Kanékés and the other seven lived in Kanékés, but this needs further investigation.

My information in 2014 was that there were now five hamlets in what used to be the dangka Kompol: Cicengal 1, Cicengal 2, Cikaréo/Cikarého, Cirancak and Lebak Kiara. Erwinantu (2012: 88) lists 4 dangka hamlets in the Kompol complex: Kompol, Ceupakbuah, Cikaréo and Cicengal. These last three hamlets have grown out of Kompol, that is, became new settlements (babakan) near Kompol. Kurnia and Sihabudin (2010: 74-5) mention that the Kompol hamlets administratively form 5 RT in the larger RW o8 of Sangkanwangi village, Leuwidamar district, Lebak regency: Kompol 1 (RT O1), Kompol 2 (RT O2), Cikaréo (RT 03), Cepak Buah (RT 04) and Cicengal (RT 05).

Sam, Abdurachman and Zarkasih (1986: 11-12) commented on the conflicting information about the number of inhabitants in dangka hamlets. They described the dangka land claimed by the Baduy as patches (kantong-kantong) considered to be 'land given by the ancestors' (tanah titipan karuhun), and that had to be safeguarded (Sam, Abdurachman and Zarkasih 1986: 10-12). They listed seven dangka hamlets outside Kanékés, as given in our Table 1 and in Figure 13 above, although there were no Baduy living in Cihandam, Kamancing and Panyaweuyan at that time.

Danasasmita and Djatisunda (1986:14-15) were less clear in their information on dangka hamlets. They noted that possibly 'in the beginning' there were 9 dangka hamlets, but now there were only two left: Kompol and Cibengkung. However, on page 21 they mentioned the existence of a total of seven jaro dangka: five have their residence (berkedudukan) outside Kanékés (Cibengkung, Cihandam, Garéhong, Kamancing and Kompol) and two have their residence inside Kanékés (Kaduketug and Cihulu). Adimihardja (2000: 51-52) referred to Danasasmita and Djatisunda (1986: 14) and also mentioned that at one point in time (before 1985) there were seven dangka hamlets, of which four were outside Kanékés (Kompol, Cibengkung, Kamancing, Cihandam) and three inside Kanékés village (Nungkulan, Garéhong and Panyaweuyan). This very much contradicts what has been consistently reported since Spanoghe (1838). 
The main problem seems that Danasamita, Djatisunda and Adimihardja did not clearly distinguish between the (sacred) dangka land that remained fixed during the last few centuries, the residence of the jaro dangka that moved in certain periods, and the number of Baduy inhabitants of a dangka hamlet that was sometimes equal to zero.

The information on dangka hamlets as given by Kurnia and Sihabudin (2010: 114) is even more confusing. In the table 'Name and location of the dang$k a$ in the Baduy area' Kurnia and Sihabudin gave the 'original seat' (kedudukan asal) of five of the nine dangka hamlets to be in Kanékés. They did this without referring to the fact that their findings contradict what has been mentioned in earlier literature. ${ }^{9}$

As regards the dangka hamlets, the most important point for us is that there still are about 600-700 Baduy living in dangka hamlets outside Kanékés. The official heads of these dangka hamlets are called jaro dangka. They play an important role in the socio-political system and their main function is to assist the other leaders with enforcing Baduy customary law. As the Baduy face a great shortage of agricultural land, the sacred dangka lands will undoubtedly also be an economical issue in the coming years.

The Baduy need for agricultural land and the related position of the dan$g k a$ lands is not unique and it has a long history in West Java. In the 19th and oth centuries the colonial government had sold much land to private owners and this led to 'excessive demands in taxes and services' on the peasants who protested against this (Kartodirdjo 1973: 21). This is also the theme of the Max Havelaar novel by Multatuli that discusses the situation in Lebak in the mid19th century (Multatuli 1860). ${ }^{10}$ Kartodirdjo (1973), writing about the protest movements in rural Java in the nineteenth and twentieth centuries, pointed out that land was the main means of livelihood of the peasantry and their

The book by Kurnia and Sihabudin (2010) offers some interesting data but lacks accuracy and references to existing literature. It is surprising that, without discussion, they list five 'original seats' inside Kanékés, whereas Van Tricht (1929), Geise (1952), Sam, Abdurachman and Zarkasih (1984) and Garna (1988) all stated that there are seven dan$g k a$ hamlets outside Kanékés, something that was also confirmed by my fieldwork data. In the 2010 s the Lebak authorities started to show interest in Multatuli and his novel about the extortion by colonial and Indonesian civil servants. In 2017 the Multatuli Museum was established in Rangkasbitung and officially inaugurated on 12 February 2018. This indicates a policy change as compared to the reaction to the 1976 Max Havelaar film by Fons Rademakers (available on YouTube) that was forbidden in Indonesia until 1987 (see https://nl.wikipedia.org/wiki/Max_Havelaar_(film)). The Lebak authorities are hoping that the Multatuli Museum will also attract tourists to Banten and Lebak. See also http://www.bbc.com/indonesia/majalah-391376o1 and https://gpswisataindonesia.info/ 2017/10/wisata-sejarah-di-kabupaten-lebak/[last access 14 February 2018.] 
'central demand was for the redistribution of land' (p.6). Kartodirdjo further pointed out that because of their organizational network via pesantren (Islamic schools) and tarékat brotherhoods and the teacher-student (guru-murid) relations '[T] he religious elite, either hadji (Mecca pilgrim), kjai or guru (religious teachers), became a major factor in the development of traditional social movements'. (p.7, 70-72). However, in the discussion of the Ciomas (southwest of Bogor) affair in 1886 he stated that the long term economic factors eclipsed all other factors, and that these movements - even the apparently religiously-oriented ones - were really concerned to redress economic grievances'. In the Ciomas movement the protests made use of the religious leaders and Muslim ideology, but were in fact based on 'strictly economic claims' (Kartodirdjo 1973: 31-32). The Baduy case should be investigated in this wider context.

\subsection{Agricultural Land, Non-Irrigated Fields and Religion}

The main problem for sustainable development of the Baduy is the shortage of land for their shifting cultivation on huma in Kanékés. Much of the Inner Baduy area consists of sacred forest and cannot be used for agriculture. That was no problem a few centuries ago, but it became a serious problem at least since the 1970s, because the number of Baduy increased rapidly: see Table 2.

In fact, for at least two centuries the Baduy have organized their own yearly 'censuses'. Each year during the (nga)laksa ritual in the last kawalu fasting month at the end of the agricultural year (around March-May) the Baduy make a 'puppet' for each human being in their hamlets, according to the three categories male (tombak), female (anak-anakan) and 'babies still in the womb' (téké golér). The total number of puppets is counted in this annual census and is a source of information for the size of the Baduy population. See Spanoghe (1838: 300-302), Geise (1952: 57-58) and Garna (1988: 336-337); see also clear pictures and a short description in Hasman and Reiss (2012: 30-31).

The recognition of the borders of Kanékés village by the sultan of Demak around the year 1800 (see Appendix 1), and later the colonial Dutch Indies government and the Indonesian government, has been a great help for the Baduy to protect their sacred forest and agricultural land from outside intrusion. They could organize their own institutions and have their own regulations. However, nowadays these borders no longer guarantee sustainable development because of the greatly increased number of Baduy living in Kanékés. It seems 
TABLE 2 Number of Baduy from 1822-2016 The numbers in square brackets [...] are my estimates

\begin{tabular}{|c|c|c|c|c|c|c|c|c|}
\hline Year & 1822 & 1888 & 1899 & 1928 & 1966 & 1983 & 2004 & 1 May 2016 \\
\hline Source & $\begin{array}{l}\text { Blume } \\
1993 \\
{[1822]: 31}\end{array}$ & $\begin{array}{l}\text { Jacobs \& } \\
\text { Meijer } \\
\text { 1891:44-46 }\end{array}$ & $\begin{array}{l}\text { Van } \\
\text { Tricht } \\
\text { 1929: } 78\end{array}$ & $\begin{array}{l}\text { Van } \\
\text { Tricht } \\
\text { 1929: } 71\end{array}$ & $\begin{array}{l}\text { Garna } \\
\text { 1988: } 5^{8}\end{array}$ & $\begin{array}{l}\text { Garna } \\
\text { 1988: } 59\end{array}$ & $\begin{array}{l}\text { Van } \\
\text { Zanten } \\
2004\end{array}$ & $\begin{array}{l}\text { Secretary } \\
\text { Kanékés }\end{array}$ \\
\hline $\begin{array}{l}\text { Inner } \\
\text { Baduy }\end{array}$ & 188 & 184 & - & 140 & - & 472 & [8०o] & {$\left[\begin{array}{ll}1 & 200\end{array}\right]$} \\
\hline $\begin{array}{l}\text { Outer } \\
\text { Baduy }\end{array}$ & - & - & - & 740 & - & 4102 & {$\left[\begin{array}{l}6 \\
6\end{array}\right.$} & {$[10$ ooo $]$} \\
\hline $\begin{array}{l}\text { Dangka } \\
\text { hamlets }\end{array}$ & - & 107 & - & 639 & - & - & [400] & [700] \\
\hline Total & - & 291 & 1387 & $15^{19^{a}}$ & 3935 & 4574 & [7 70o] & $11289^{b}$ \\
\hline
\end{tabular}

a On page 78 Van Tricht gives a total of 1521 .

b This figure is a total for Kanékés village without the 7 dangka hamlets outside Kanékés. The secretary said he did not have figures for Baduy living in the dangka hamlets outside Kanékés. I estimate their number at about 700 in 2016, so that at that time the total number of Baduy was about twelve thousand.

that the major conflicts between Baduy and their non-Baduy neighbours were caused by problems over land ownership. Therefore, in 1978 the Indonesian authorities opened the first Baduy resettlement hamlet Cipangembar in an old rubber estate Gunung Tunggal, in bird-flight about $15 \mathrm{~km}$ north of Kaduketug. This resettlement project failed almost entirely and many migrants returned to Kanékés (Bakels and Boevink 1988: 66-121; Garna 1989: 28; Persoon 1994: 309-372; Van Zanten 2004: 130-134). The great pressure for agricultural land remained and was even enlarged by the many dangka inhabitants that moved to hamlets inside Kanékés village, as was mentioned in Section 2.2. The Indonesian authorities were getting more grip on the Baduy way of life since the resettlement projects that started in 1978 (Van Zanten 2004).

In the Outer Baduy area there is about 2000 hectare huma available for farming and this is not enough for the present population. Moreover, the Baduy way of farming on non-irrigated fields with shifting cultivation requires much farming land. For this 'slash and burn' farming without fertilizers and without pesticides, ${ }^{11}$ the land should only be used for farming one out of five to seven

11 Although pesticides have not been used for rice, vegetables and fruit, in July 2016 I saw a man with chemicals in plastic containers near the house of the secular village head. He told that this was used to spray grass away (A2016-2: 1). During the last decades pollution 


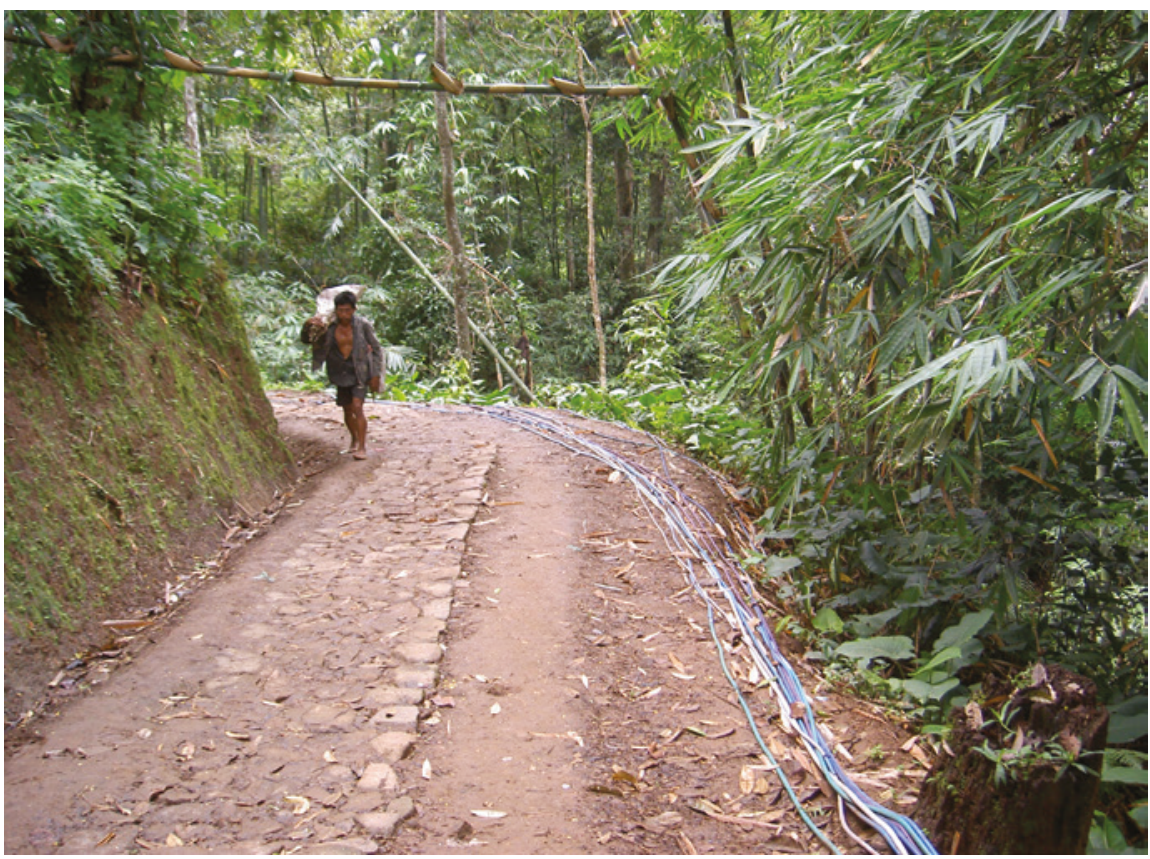

FIGURE 14 Clean water used to be transported by gutters made of lengthwise cut bamboo.

This is gradually replaced by a system of PVC pipes lying on the ground. Path near Kaduketug 1, 11 December 2013

years. Currently the land seems to be used every other year for growing rice. It means that the quality of the agricultural land is decreasing: the land becomes exhausted. This forced many Outer Baduy to work on fields outside Kanékés. ${ }^{12}$ They bought the land, or hired it to be used for farming. I have no sound data on how much land the Baduy are using outside Kanékés, but it is fairly certainly more than what they have in Kanékés. In July 2016 jaro pamaréntah Saijah told me that the Outer Baduy possess or rent about 3000 hectare farming land outside Kanékés (A2016-1: 59).13

by plastic, PVC and batteries also has become a problem, partially because of tourism, but also because materials like bamboo are being replaced by the Baduy themselves (see Figure 14).

12 As far as I know Inner Baduy should still have their huma exclusively inside the Inner Baduy area in Kanékés and they all obey this rule.

13 Confusingly, in December 2013 the secular village head Daénah had told me that Baduy people possess about 700 hectare of agricultural land (huma) and hire another 300 hectare huma outside Kanékés village (A2013: 30). This is different from what I reported in 2004, namely that in 2003 more than half of the Outer Baduy agricultural 
Many Baduy already work on land owned by others and this land lies about one hour travelling by foot and public transport from their homes in Kanékés. In such cases they will build a small house near the fields (saung huma) and stay there most days during the week at the time that much work has to be done there. In July 2016 the former secular village head jaro Asrab told me that in Cikapék near Leuwidamar, where his son and several other Baduy have agricultural fields, the price for one hectare land was about 6o million Rupiah, that is, about $€ 4140$, Us $\$ 456$ o. A few years earlier his son-in-law and daughter had bought 2 hectare land for 100 million Rupiah in Cikapék (A2014-1: 21). There also are Baduy families who do not possess or hire any farming land. Those people are forced to find other forms of living, like trading cloths woven in Kanékés, forging knives, etcetera. This is becoming a serious problem, because farming on non-irrigated rice fields has always been a central pillar of the Baduy religion Sunda wiwitan. ${ }^{14}$ Danasasmita and Djatisunda (1986: 7980) and Garna (1988: 278) emphasize that Baduy religion is not about what Baduy should believe, but about what they have to do according to the ancestral rules. ${ }^{15}$

Geise (1952:100-101) reported that some Baduy complained that there were sawah on the dangka fields outside Kanékés. His informant Marceuni (Martjeuni) remarked that it was all right if some regulations on Baduy clothing were changed, but sawah should not be allowed to replace huma:

fields was located outside Kanékés; one third of land in the village Bojong Ménténg belonged to Baduy people (Van Zanten 2004: 131). However, both statements by Daénah point to the fact that Outer Baduy are using a considerable amount of fields outside Kanékés.

14 I use 'religion' in the sociological/anthropological way: the hierarchically highest classification system in a society. Therefore, I make no great distinction between the concepts 'religion' (agama) and 'belief system' (kepercayaan) or 'local religion': both are covered by the term 'religion'. However, this distinction is clearly made by the present Indonesian government. It is not entirely clear when Sunda wiwitan was first generally used to indicate one of the (mystic) belief movements in Java (aliran kepercayaan, aliran kebatinan) and when the Baduy started to use this term for indicating their own religion/belief system. Mutaqin (2014: 10, 18) states that at the beginning of the 2oth century the teacher Madrais had 'formally established a new religion called Agama Djawa Sunda (ADS) which later became well known as Madraisism or Sunda Wiwitan' in Kuningan (south of Cirebon), west Java and '... Sunda Wiwitan - the other name for ADs.' Subagyo (1976: 99) used 'Agama Sunda' to describe the Baduy religion and he did not mention 'Sunda wiwitan'.

15 Danasasmita and Djatisunda (1986: 288): '... agamanya [Baduy] tidak menekankan kaidahkaidah kepercayaan'. Garna (1988: 278): '... pikukuh berisi dan menekankan kepada apa yang harus mereka lakukan atau kerjakan bukan kepada apa yang harus dipercayai.' 
For all jaro dangka this is forbidden [to have irrigated fields]. It seems that nowadays they violate religion, after it has been crushed by the jaro pamaréntah. Because those jaro say: 'According to government's order'. Therefore the jaro dangka are afraid of them.

Geise continued by saying that he quoted Marceuni's 'sermon' because it underlines how important the restrictions on land use are. 'It is of utmost importance to consider the land, the sacredness of the land and preservation of that land as one of the most important cultural elements of the Baduy, next to the rice ritual'.

This situation did not change since Geise's research: in current practice irrigated rice fields (sawah) are strictly forbidden in Kanékés. This also holds for the fields near the hamlets of Cicakal Girang in Kanékés, where Muslim people live. The sawah there (see Figure 15) are only tolerated by the Baduy rulers, because they have no power to change this situation. Danasamita and Djatisunda (1986: 90) described the task of the Muslims living in Cicakal Girang in the past as 'spies for the kingdom', that is, for the sultanate of Sérang. ${ }^{16}$

One could say that the role of the Muslim enclave Cicakal Girang is to mediate between the Indonesian rulers and the Baduy. Until this day Outer Baduy have their marriage registered by the panghulu (Islamic religious village officer) of Cicakal Girang. When married this way the Baduy have no problem in saying, with consent of their spiritual leaders (puun), the Muslim creed (sahadat, syahadat: 'There is no God but Allah, and Muhammed is his Prophet'), mainly because to them this does not mean that they are Muslims (Danasasmita and Djatisunda 1986: 92-93). See also Sucipto, Limbeng and Maria (2007: 92). Moreover, Danasamita and Djatisunda (1986: 71) remarked that the puun only give permission to marry this way, if the Outer Baduy couple has promised not to become Muslim; see also Section 4.6. In a section about the Muslim enclave Cicakal Girang, Kurnia and Sihabudin (2010: 78-84) quoted a few important Baduy who all confirmed that this hamlet in Kanékés has been Muslim from the beginning and that it is not a place where Baduy go to become Muslim.

Suryani ([2020]) wrote an interesting section on Cicakal Girang in chapter 4, based on his fieldwork in 2017-2018. See also Mutaqin (2014: 1-2) who wrote about people adhering to the Agama Djawa Sunda (ADS) that he also called Sunda wiwitan: 'As a pragmatic response when being repressed, either by religious

16 See also Subagyo (1976: 95) who argues that sultan Maulana Hasanudin of Banten (seat in Sérang) spread Islam with arguments and without using force or harshness. Therefore the Islamic enclave Cicakal Girang could be built in Kanékés as the result of a compromise. 


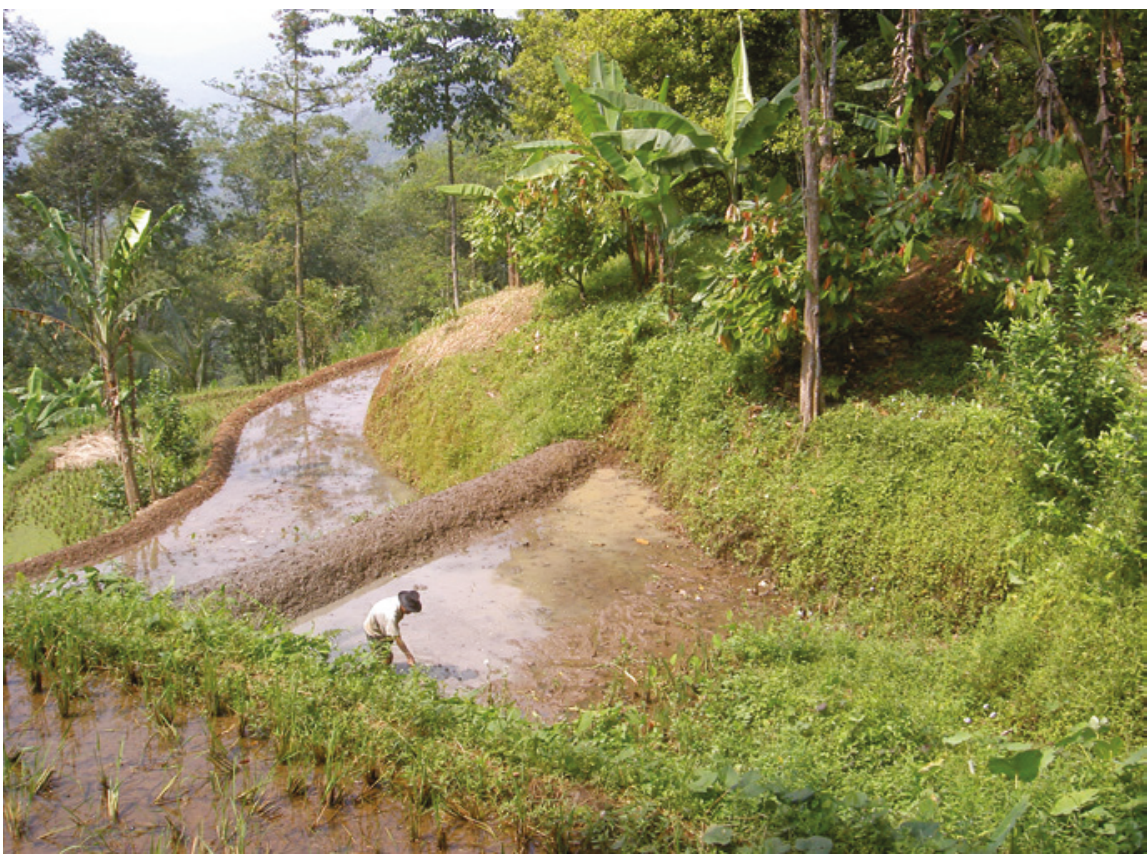

FIGURE 15 Irrigated rice fields (sawah) of Muslims living in the hamlets of Cicakal Girang in Kanékés are officially forbidden, but nevertheless tolerated by the Baduy leaders. Cicakal Girang, 2 June 2014

orthodoxy or the state, ADS utilises a "back and forth" conversion tactic. The "front stage" is the pretence of converting to one of the formal authorised religions ${ }^{17}$ whilst at the "back stage" they remain true to their beliefs'. Mutaqin (2014:18-20) gave a few recent examples of how followers of the Sunda wiwitan belief system applied the 'back and forth' conversion tactic in other parts of Sunda.

\subsection{Relations with Indonesian Authorities and Cultural Tourism}

The Baduy have always recognized that they were part of a larger system. ${ }^{18}$ Their ascetic life is for the well-being of the world and they could live this

17 The six official religions and percentages of the population given by the Indonesian Ministry of Religion are: Khonghucu (0.05\%), Buddha (0.7\%), Hindu (1.7\%), Katolik (2.7\%), Protestan (6.9\%), Islam (87.2\%); see https://indonesia.go.id/profil/agama [last access 19 January 2019.]

18 This section includes parts taken from Van Zanten (2017). 
life, because the sultans of Banten had guaranteed the borders of their village Kanékés. In return, the Baduy have paid their respect to the sultan of Banten by offering agricultural products (like bananas, palm sugar, petai beans) and handicrafts (like woven cloths, kitchen utensils) during the yearly séba ceremony after the harvest. Nowadays the Baduy are protected by other 'rulers of the north' than the sultan: in particular the head of the sub-district Leuwidamar, the regent of Lebak in Rangkasbitung, the regent of Sérang and the governor of Bantén Province in Sérang. Although the Baduy have been granted a great deal of autonomy in their village Kanékés, in colonial times and also in the independent Indonesian state, the relation between the indigenous group of the Baduy and the Indonesian authorities showed serious shortcomings with respect to sustainability (Van Zanten 2004).

Around 2001 the Banten provincial government declared the Baduy area an 'object of cultural tourism' (obyek budaya wisata) and this encouraged visits from outsiders (Van Zanten 2004: 145-147). Undoubtedly there were some benefits for Baduy: they sold more locally woven cloth and knives made by their smiths to tourists. ${ }^{19}$ In 2015 the blue-black printed batik (mérong) used by Outer Baduy for the men's head cloth and women's sarong and produced outside Kanékés, was patented as Batik Lebak; see also Figure $16 .^{20}$

However, these developments also had negative effects. The accommodation of an increasing number of tourists visiting Kanékés village became a burden for the Baduy. For instance, hamlets of about 400 people in Kanékés were sometimes asked to accommodate a group of tourists of the same size for one or two nights. In a newspaper article former minister of Education and Culture, Fuad Hassan was quoted as saying in 2002: 'The Baduy area and the Naga village in Tasikmalaya seem to be only exploited, without any benefit for them'. (Van Zanten 2004: 145-147).

In a newspaper article of 15 June 2009 a Dutch journalist reported that she visited Kanékés with two friends. When in Cibolégér they wanted to be guided by Baduy boys into Kanékés, they were told by other men that they could not 'just take a Baduy guide'; the Baduy could only carry their luggage. The journalist wrote: 'This was also an acquaintance with the local Javanese preman: the local scoundrels who have set up a whole business around

19 E-newspaper Kompas.com 29 October 2014 [last access 23 May 2017]: https://travel. kompas.com/read/2014/10/29/194100627/Wisatawan.Mulai.Lirik.Kain.Tenun.Baduy and Kompas.com 28 October 2015 [last access 23 May 2017]: https://travel.kompas.com/read/ 2015/10/28/071200827/Tenun.Tradisional.Baduy.Disukai.Wisatawan.

20 See a list of the twelve Batik Lebak motifs on https://batikdarilebak.blogspot.nl/. [Last access 22 August 2017.] 


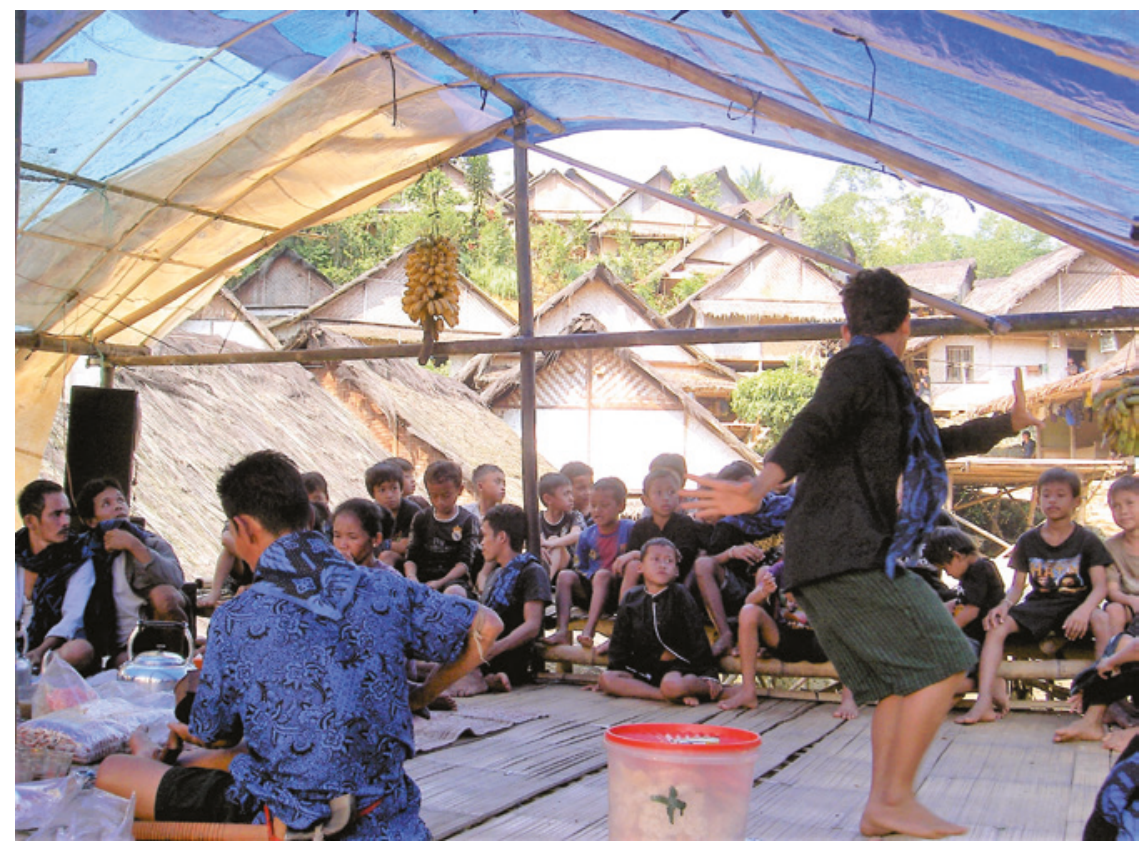

FIGURE 16 Boy dancing on keromong (gamelan) music during a circumcision in Cicakal Leuwi Buleud, 5 July 2016. This dancing (topéng) is officially forbidden, but tolerated for Outer Baduy.

their less mature neighbours'. She was not the only one with this experience and this type of exploitation seems to have become even more problematic nowadays. ${ }^{21}$

One problem that comes with tourism, is that often foreigners, who are not allowed to enter the Inner Baduy area, nevertheless do enter and try to meet a puun, which is forbidden. Some of the foreigners wrote about this. For instance, the German journalist Thomas Hanitzsch wrote about his visit to the Inner Baduy in September 2000. An Inner Baduy guide, most probably from Cibéo, took him there for a meeting with the puun, under the condition that he would cover his white skin and would not take photographs. ${ }^{22}$ I have heard about and experienced more examples of this. For

21 See Elske Schouten's article 'With a dubious guide to the Baduy' on https://www.nrc. nl/nieuws/20og/o6/15/met-een-dubieuze-gids-naar-de-baduy-a1479226. [Last access 12 April 2018].

22 See newspaper article 'Die "Baduy" von Kanekes.' Freitag 39, 22 Sept 20oo, https://www. freitag.de/autoren/der-freitag/die-baduy-von-kanekes [last access 21 February 2019.] 
instance, in July 2016 a Korean Christian preacher was expelled by the Outer Baduy, after giving sweets to Baduy children and telling them to thank God for this. Earlier the preacher had openly told me that he had met the puun of Cibéo with his party of about 5 o students, including several Koreans (A2016-1: 30-31, 47).

\subsubsection{Hand Phones}

Baduy ascetics are also tempted by new technological developments: motorbikes, cars and also by hand phones/cell phones (hapé, ponsel). Familiarity with these technological developments starts already at a young age, when children watch television just outside Kanékés and play, for instance, card games: see Figure 17. Of these developments I think that the hand phones have a tremendous impact on Baduy society, because they may be very useful. A decade ago Bart Barendregt wrote: 'Hence, in Indonesia one cannot overstress the representational value of mobile media'. (Barendregt 2008: 160). Similarly, the impact of hand phones on Baduy society should not be underestimated, not only for 'representational values', but also for the practical consequences.

Although officially still forbidden by the spiritual leaders, almost all Outer Baduy grown-ups in the northern part of Kanékés have such hand phone (smart phone) and they carry it with them. It is said that also many Inner Baduy have a hand phone and that they leave it behind in Cibolégér or some other place before entering Kanékés. The hand phones greatly stimulate the Baduy to informally learn to read and send messages, record sound and images on their smart phone, or search the Internet. ${ }^{23}$ The phones are, for instance, used for inviting an angklung group to play outside Kanékés. The hand phones are also used to make arrangements with tourist groups that want to visit Kanékés. In a newspaper article of 7 February 2019 the journalist wrote that the editorial office had contacted the secular village head Saijah (Saija) for an interview by telephone. ${ }^{24}$

The history of the hand phones in the Baduy area started around 20082009, considerably later than in the urban areas. On 13 May 2009 the general

23 See, for instance also Kompas.com with the 2010 article 'The Baduy produce independent souls': https://tekno.kompas.com/read/2010/03/27/0242138/jiwa.mandiri.bertumbuh.di.baduy [last access 26 February 2019.]

24 In this interview Saijah announced the dates of the kawalu months for ritual cleaning and fasting: between 5 February and 5 May 2019. Kanékés would be closed for tourists at that time, he said. See https://regional.kompas.com/read/2019/o2/o7/20065791/gelar-ritualkawalu-kawasan-wisata-baduy-dalam-ditutup-tiga-bulan. [Last access 10 February 2019.] 


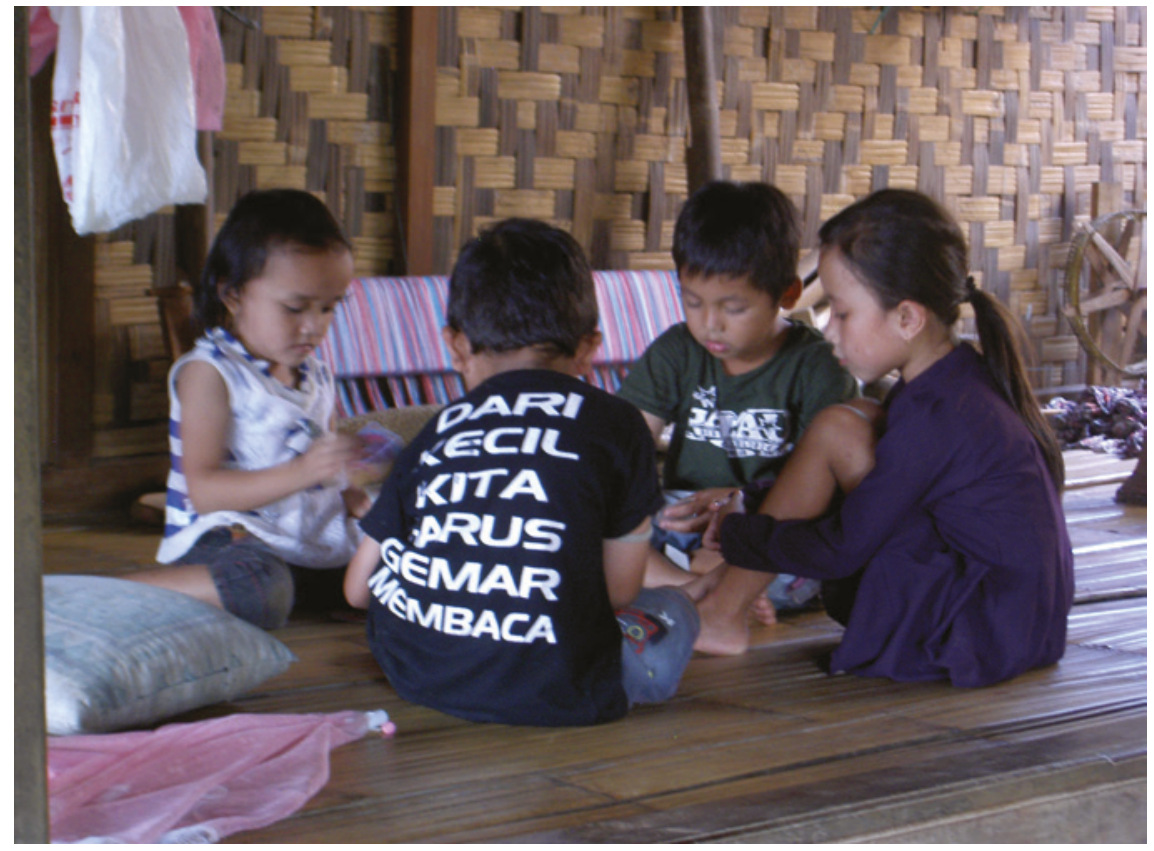

FIGURE 17 Children playing cards on the veranda of the village head in Kaduketug 1, 29 May 2014. The text on the shirt means: 'As from a young age we have to enjoy reading'

manager Johnny Swandi Sjam of Indosat Company, a provider of telecommunication, officially opened the first base transceiver station (вт)) in Cibolégér, which made the operation of hand phones in Kanékés possible (Figure 18). The opening happened in the presence of the vice-governor of Banten, Muhammad Masduki. The general manager of Indosat made it clear that this telecommunication tower would stimulate tourism to the Baduy area. It had already been operational since 2008. According to the Internet newspaper Republika the general manager said on that occasion:

Our presence in the hamlet Cibolégér that borders the Baduy area again proves Indosat's commitment to opening up the access to services for the people in the rural areas, so that they can develop the potentials of their area, such as tourism in the Outer Baduy area that is known as an area where tourists go, because of its unique tradition and culture they defend until the present day. ${ }^{25}$

25 See http://www.republika.co.id/berita/trendtek/telekomunikasi/og/o5/14/5o119-indosatperluas-layanan-ke-baduy. [Last access 24 January 2019.] 


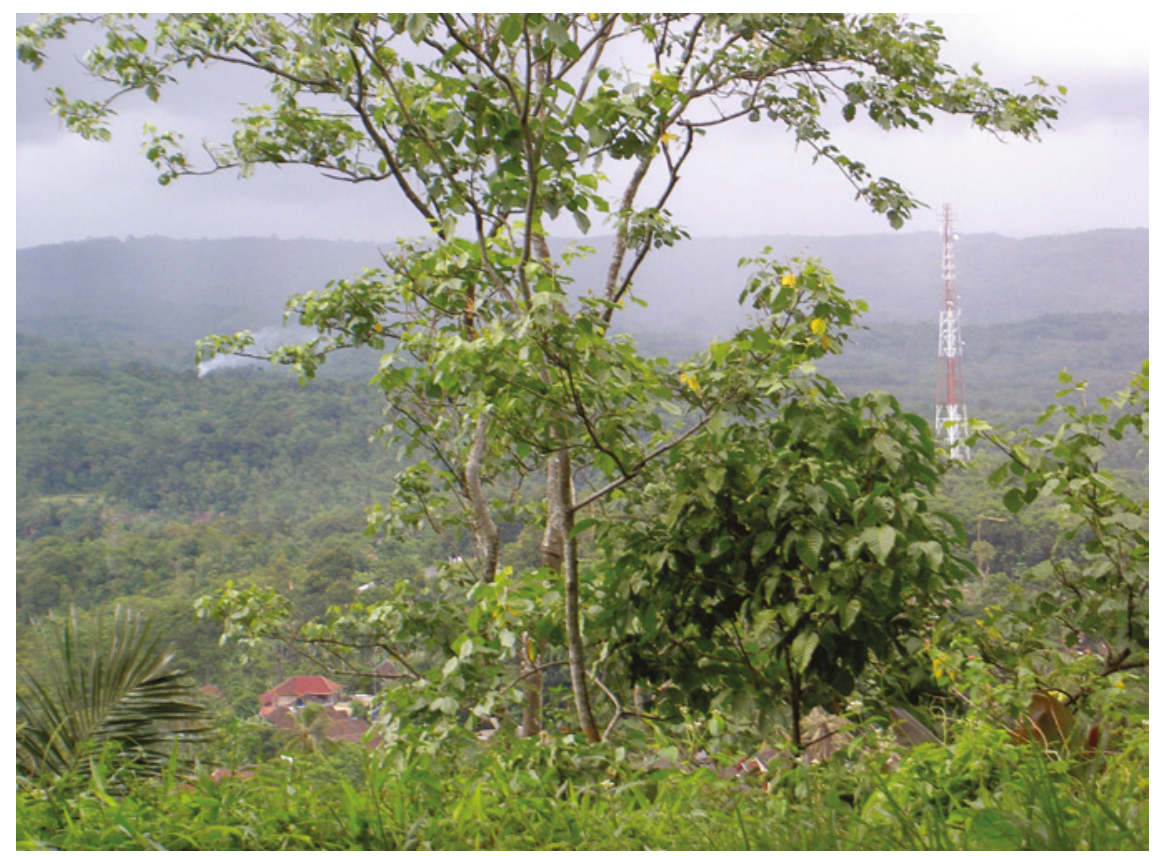

FIGURE 18 In the right-background is a Base transceiver station (BTS) enabling communication by hand phones, Cibolégér/northeast of Kanékés, 14 December 2013

The vice-governor of Banten added to this: 'By supplying access to telecommunication in the Baduy area, we hope that we can help to raise the touristic potential of this area. ${ }^{26}$ However, there also appeared negative reactions to these developments.

On 28 August 2012 a critical E-newspaper article 'B Ts, Baduy, Prometheus and common mistakes' appeared about these hand phone facilities created for the Baduy. ${ }^{27}$ The journalist Heru Nugroho and his travelling party reported on a telecom tower (втS) that they had seen in the process of being built in Cijahé, just outside Kanékés, and in bird-flight between 1 and $2 \mathrm{~km}$ from the three Inner Baduy hamlets Cikeusik, Cikartawana and Cibéo (see map in Figure 2). Until then these three hamlets had not been in reach of this telecom network. The tower was built by an Indonesian provider of telecom facilities, most probably Indosat. The journalist and his party were

26 See http://inet.detik.com/read/2009/o5/13/160943/1130865/328/indosat-buka-akses-dipedalaman-baduy. [Last access 24 January 2019.]

27 See http://www.wacana.co/2012/o8/bts-baduy-prometheus-dan-salah-kaprah/[last access 24 January 2019.] 
surprised to find here such a tower: What did the Baduy gain from this? Had the company carried out a feasibility study that not only included the business components, but also the cultural and social effects? Did the company really think about the implications this telecom system would have for the Baduy community?

It would be interesting to know more details about why Baduy buy hand phones and how they use them. Do they mainly use prepaid cards, how often do they speak on the phone and how often do they send an SMS, make photographs or films, use the Internet, etc.? Further, it would be interesting to know more details about the role of telecom companies in the spread of hand phones. In such study on the telecom facilities supplied by companies the role of NGOS and the local and provincial authorities should be included. I suppose most Baduy users, like many others using this technology, have little idea about the possible misuse of their private data and the spread of fake news when using these telecom facilities.

\subsubsection{Séba}

During the last decennium the authorities of Banten province very much promoted Baduy people to participate in the yearly séba ceremony. In this ceremony, taking place after the rice harvest, a delegation of Baduy men travels to Rangkasbitung and Sérang to pay their respect to the local rulers and offer them some of their agricultural and handicraft products. In Sérang they also reconfirm the ritual relation to the rulers: Outer Baduy who for the first time take part in a séba take a ritual bath in the Cibanten River; Inner Baduy do so in the Cigowel River. ${ }^{28}$ The séba ceremony fits very well with the policy of making the Baduy an object of cultural tourism. Whereas in 1905 the séba delegation consisted of seven Baduy (Pleyte 1909: 494), about a century later its size increased from about 500-600 Baduy participants in 2003 to almost 2000 in $2015 \cdot{ }^{29}$

In current practice participating Baduy men are paid for taking part in the séba ceremony (during the last few years about 50 ooo to 100 ooo Rupiah, or between $3^{1 / 2}$ and 7 Euro, or 3.8 and 7.6 us dollars) and the governmental

28 Personal information from Mumu, 26 April 2015. See also jaro Saijah, as reported by Bahtiar Rifa'i in DetikNews 2o April 2018 on https://news.detik.com/berita/3982289/ nyeker-seribuan-warga-baduy-jalan-kaki-5o-km and http://travel.kompas.com/read/ 2015/o5/26/143944427/Seba.Perjalanan.Spiritual.Baduy [last access sites: 16 March 2019.]

29 This number of séba participants also fluctuates for other reasons. If the harvest has been good, there are many participants and it is called a 'great séba' (séba gedé); if the harvest is not so good there will be less participants and it is called a 'small séba' (séba leutik). See also Appendix 2. 
authorities promote the ceremony to tourists. Already for a few years the authorities arranged transport for the Outer Baduy at the séba ceremony. On 20 April 2018 they had arranged for 78 trucks to transport the about 1350 Outer Baduy to Rangkasbitung and Sérang (Mumu, personal communication 25 April 2018). ${ }^{30}$ In 2019 there were protests against the change of the séba meeting with the governor of Banten in Sérang from 9 May 2019 (Thursday) to 4 May 2019 (Saturday). Many Baduy felt that the change of date was 'forced on them', and they refused to take part in the séba: dates determined by the spiritual leaders cannot be changed easily, just because a Saturday would possibly be better for tourists.

In July 2016 I saw an official letter on the sign board in the Baduy secretariat in Cibolégér, signed by jaro pamaréntah Saijah and dated 18 April 2016, announcing the timetable for the coming séba ceremony in May 2016. This letter was officially directed to the Governor of Banten Province in Sérang and the Regent of the Lebak Regency in Rangkasbitung. Altogether 1839 Baduy men had registered for participating in the 2016 séba: 50 from Cibéo, 11 from Cikartawana, 30 from Cikeusik and $175^{2}$ Outer Baduy from the other 62 hamlets. These figures are not entirely consistent and the total number of participants apparently turned out to be much less: 1317, 1300 Outer Baduy and only 17 Inner Baduy participants (see Appendix 2).

In this letter about the 2016 séba programme the timetable for the party of participants, based on a decision of the Tangtu Tilu Jaro Tujuh Adat Board of the Baduy community, was given to be:

1. Friday 13 May 2016, 01:30 [13:30]: departure from the office of the village head of Kanékés to the regents' office of Kabupaten Lebak [in Rangkasbitung]. ${ }^{31}$ Presentation of the Baduy séba gifts in Kabupaten Lebak on Friday evening (malam Sabtu);

2. Saturday 14 May 2016, 07:30: Séba participants will depart from Rangkasbitung and go to [the seat of] Banten Province. Presentation of séba gifts in Banten Province [Sérang] on Saturday evening (malam Minggu);

3. Saturday 14 May 2016, 10:00 until ready: [visit] to the Adat Institute for Séba (Lembaga Adat Seba) in Pandeglang Regency;

4. Sunday 15 May 2016, 8:30 in the morning: Séba in the Kabupaten Sérang, followed by the return of the séba participants to the Baduy area.

30 See also https://www.merdeka.com/peristiwa/pelaksanaan-dimajukan-seba-baduy-2o19berlangsung-kurang-meriah.html.

31 Whereas the Outer Baduy may use public transport, the participating Inner Baduy will have to walk from Kaduketug to Rangkasbitung, a distance of about $5^{2} \mathrm{~km}$ according to Hasman and Reiss (2012: 33). Therefore this letter was not meant for the Inner Baduy. 
During the séba the Baduy usually also publicly state what they want the Indonesian authorities to do for them and the world. For instance, the issues of land shortage and religion were raised during the 2016 séba and summarized in an article in the Internet newspaper Merahputih.com of 14 May 2016. ${ }^{32}$ Secular village head Saijah was reported to have asked the regent of Lebak in Rangkasbitung:

1. That on Baduy identity cards (КтP) in the column 'religion' would be written 'Sunda wiwitan', as was the case from about 1972 to 2011 (it should not be kept empty, as has been the case since 2011);33

2. The Baduy would like to be involved in protecting the sustainability of nature (dilibatkan menjaga kelestarian alam) in the Gunung Halimun National Park;

3. To help in obtaining six hectare of land to be used for agriculture, because there is a shortage.

To these questions the Lebak regent Iti Octavia Jayabaya answered ${ }^{34}$ that her local government, like other Lebak governments before, would support the Baduy request that 'Sunda wiwitan' would appear on their identity card, however, this was a matter under the judicial power of the central government. ${ }^{35}$ Further, she supported the efforts of the Baduy for sustainable development of nature in Banten. The report in the E-newspaper did not mention how the regent answered to the question of obtaining six hectare of agricultural land for the Baduy.

32 https://www.jpnn.com/news/masyarakat-baduy-punya-3-permintaan-ini; last access 28 September 2020 .

33 Although the Baduy insist to get 'Sunda wiwitan' back on their identity card, several Indonesians have principally objected against a column 'religion' on the identity card and allowing only six religions to be included (Islam, Protestantism, Catholicism, Hinduism, Buddhism and Confucianism), as this may cause discrimination. See, for instance, the 17 May 2016 Internet article at https://merahputih.com/post/read/kolom-agama-di-ktpjadi-pemicu-terjadinya-diskriminasi [last access 9 January 2018]. On the identity card the column 'religion' could be left blanc if a person wishes so, but this does not solve the problems of possible discrimination.

34 See https://www.jpnn.com/news/masyarakat-baduy-punya-3-permintaan-begini-tanggapan-bu-bupati; last access 28 September 2020.

35 In 2017 the Constitutional Court ruled that the indigenous religions could be registered on the indentity cards (КTP). This resulted in the possible registration of 'religion' as 'belief in the Almighty God' (Kepercayaan terhadap Tuhan yang Maha Esa). It did not really solve the Baduy problem: they wanted their religion to be notated as 'Sunda wiwitan' (Suryani [2020]: chapter 7, section E); see also, for instance, https://daerah.sindonews.com/read/ 1382179/174/4462-warga-baduy-miliki-e-ktp-dengan-kolom-kepercayaan-tme-1551177450 [last access 12 March 2020.] 
Religion has always been one of the important issues for the Baduy. In Van Zanten (2004: 137-141; see also Suryani [2020]) I described the difficulties some Baduy experienced when resettling in land outside Kanékés after 1978. The Baduy leaders no longer recognized these migrants as Baduy, because they had ceased to live according to the customary rules. Hence they could not be registered as having the Sunda wiwitan religion. Most of these migrants became Muslim and some became Christians and possibly Hindu. Remaining an unbeliever, atheist, agnostic or humanist was no real choice and dangerous, also because most Indonesians still associate unbelievers with communists. This was nourished by the severe social unbalance caused by the army coup of 1965. The 'systematic attack against the Communist Party of Indonesia (Partai Komunis Indonesia, PKI)' and the committed 'crimes against humanity' by the State of Indonesia ${ }^{36}$ led to a stronger position of Islamic parties and undoubtedly made the position of unbelievers and non-Muslim Baduy more vulnerable.

In Van Zanten (2004: 141) I also mentioned that during my fieldwork in Kanékés in March 2003 the Baduy closely followed the international developments concerning Iraq and a possible invasion by the USA. The war against Iraq started in the early hours of Thursday 20 March 2003. In Indonesia there was little sympathy with the United States of America and the United Kingdom, and the Baduy were no exception. The war was systematically announced as a 'war of aggression' on Indonesian television and radio. The Baduy village head Daénah listened several times per day to the radio, Indonesian news, but mostly to the Indonesian broadcast of the в вс World Service. He explained that the Baduy leaders thought, that a Third World War would be a war between religions (perang agama). They feared that when this war would start in Iraq, it would also affect them: the surrounding Muslims might then attack the small Baduy group and this would be the end of Kanékés. Section 6.5 will again discuss this issue by looking at some texts of the pantun stories.

The Indonesian authorities want the Baduy to integrate as much as possible in the Indonesian nation. This was not yet achieved in 2004: I wrote that the Kanékés people do not pay taxes to the Indonesian government, do not

36 See, for instance the 'Final Report of the IPT 1965: Findings and Documents of the IPT 1965', Section C., 1.Findings, item 1, on http://www.tribunal1965.org/final-report-of-theipt-1965/[last access 9 January 2019.] The International People's Tribunal (IPT) concluded: 'The State of Indonesia is responsible for and guilty of crimes against humanity consequent upon the commission and perpetration, particularly by the military of that state through its chain of command, of the inhumane acts detailed below ...' However, I have no data on how the 1965 army coup directly influenced Baduy society and culture. 
vote in general elections, nor send their children to school, which is compulsory for other Indonesians. On the other hand, the secular village head of Kanékés is formally appointed by the Indonesian authorities, with consent of the spiritual leaders of the Baduy, but the Indonesian authorities do not pay him a salary like they do for other village heads. The same holds for the secretary (carik) to the village head, who is always a non-Baduy person (Van Zanten 2004: 129-30). Since 2004 certain things have changed. The village secretary became an official civil servant in 2007 with a salary paid by the Indonesian authorities and the Outer Baduy started taking part in the general elections.

Erwinantu (2012: 101-2) reported that Outer Baduy gradually took part in the general elections (pemilu) since 1997. The Baduy leaders still do not allow the Inner Baduy to take part in the elections. In 1997 there were just a few hundred Outer Baduy that took part, but in 2004 the participation was much larger and in 2009 about 1500 of the 5000 people with voting rights took part. In the regional elections of Rangkasbitung in 2013 about 5000 of the 7000 Outer Baduy with voting rights actually voted, according to Sapin, the secretary of Kanékés village. ${ }^{37}$ Thus Baduy became more involved in Indonesian politics. See on this matter also Suryani's dissertation 'From hermits to citizens' [2020], chapter 7 ; he quotes sources that mention some Baduy participation in general elections in the 1970 and 198 os.

Giving voters the opportunity to elect a governor (gubernur), regent (bupati) of a regency (kabupaten), a mayor of a city, and the president of the country in direct elections was part of the democratization and decentralization process after the fall of the Suharto regime in 1998. In 2005 this became possible for the first time; before that year these officials were appointed by the central government. After the direct elections of several rather 'independent' candidates, that is candidates not closely related to a political party, the Indonesian House of Representatives (DPRI) decided to cancel the direct elections for governors, regents and mayors on 26 September 2014. After this 2 October 2014 change of law (PPPU 1/2014 and PPPU 2/2014) the president and village heads (lurah) will still be chosen by direct elections, but governors, regents and mayors will be elected in an indirect way again, via the parties in the regional parliaments

37 See, for instance, E-newspaper articles Melle Garschagen: https://www.nrc.nl/nieuws/ 2014/og/26/woede-in-jakarta-na-democratisch-verraad-1425145-a113484 and Inggried Dwi Wedhaswary (ed.): https://nasional.kompas.com/read/2014/10/o3/o9190651/ini.isi. Perppu.Pilkada.yang.Dikeluarkan.Presiden.SBY This happened by the law 'Tentang pemilihan Gubernur, Bupati, dan Walikota': see http://www.bpkp.go.id/uu/file/3/122.bpkp [all sites last accessed 9 January 2019.] 
(DPRD). It seems that after this new law of 2014 the Baduy's interest in the elections decreased again.

The attempts of the Indonesian authorities to increase its grip on Kanékés became also clear from the fact that at the time that the concrete poles ${ }^{38}$ were used to mark the borders of Kanékés in 1986, the Lebak regency also divided Kanékés in three administrative 'blocks' with one of the tangtu hamlets as its centre (Garna 1987: 21-2). Currently this administrative system seems to be the one commonly used; see also Appendix 1. The influence of the Indonesian bureaucratic system on the Baduy society may also become clear by noting that by July 2016 the size of the secretariat of Kanékés village had increased to 11 people, headed by Sapin. ${ }^{39}$

\subsection{Non-Governmental Organisations: Trust, Social Justice and Environment}

In some parts of the world Non-Governmental Organisations (NGOs, badan nonpemerintah, and lembaga swadaya masyarakat) or foundations (yayasan) have played an important role as mediators between minority groups, the majority groups and the authorities. In this section I would like to discuss the role of some NGOs as regards the relation between the Baduy indigenous group, Indonesian society, and the Indonesian and local authorities. Generally speaking, NGOs have not been very strong in Indonesia, certainly not at the time of Suharto's 'New Order' (Orde Baru) between 1966 and 1998. At that time the armed forces had a strong grip on society and they wanted social stability for economic development. With an understatement one could say that they did not encourage independent, critical voices from intellectuals, artists and NGOS.

Since 1970 there was at least one notable NGO that on behalf of the poor people raised its voice against violation of human rights, social injustice and corruption in Indonesia: the Lembaga Bantuan Hukum (LBH, Legal Aid Foundation). ${ }^{40}$ However, during the Suharto regime the general political climate in

38 The poles were painted white, that is, in the 'sacred' colour (Bakels 1993: 354).

39 Sapin was village secretary of Kanékés until 1 July 2016; he was replaced by Arman, according to my assistant Mumu, in an E mail dated 18 January 2017.

40 The LB H was founded in Jakarta in 1970 on the initiative of Adnan Buyung Nasution (19342015) and it was then supported by the then governor of D KI Jakarta, Ali Sadikin. See, for instance https://id.wikipedia.org/wiki/Lembaga_Bantuan_Hukum_Jakarta [Accessed 27 April 2017.] 
Indonesia was not favourable for NGOs. This needs to be kept in mind when discussing NGOs that were involved with the Baduy in this section. Further, I shall only briefly discuss a few of my own experiences concerning NGOs in this context. This topic is worth to be investigated more thoroughly. See Suryani ([202O], in particular chapter 4) for Muslim NGOs involved in the conversion of Baduy, especially in the resettlement hamlets, to Islam.

In the 1980s and 199os the land around Kanékés became increasingly used for oil palm (kelapa sawit) plantations. This was damaging the ecological system of the region and it worsened the problem of finding agricultural land for the Baduy, a problem that already existed for several decades and that also led to the resettlement programme of 1978 that started with resettling 80 Baduy families (see also Sections 2.2 and 5.4). Some NGOs offered to assist the Baduy indigenous group in dealing with the Indonesian authorities and the agricultural business companies. The village secretary of Kanékés, Ukang Sukarna, told me in October 1992 that the pop singer Ully Sirgar Rusadi had bought a piece of 16 hectare forest just outside Kanékés and wanted to make this a kind of natural reserve with special trees (A1992-1: 39). It was meant as an environmental protection of Kanékés and carried out by the Yayasan Garuda Nusantara, founded by Ully Sirgar in $1985^{41}$

On 5 November 1992 I visited Ully Sirgar in Jakarta. I told her that I had donated money to the village head Asrab for buying about one hectare of land outside Kanékés for communal use by the Baduy (Van Zanten 2009: 295297). On her part she confirmed that the Garuda Nusantara foundation had bought land near Kanékés on two locations: one piece of 14 hectare and one piece of 6 hectare. This action should prevent the establishment of sawit oil palm plantations around Kanékés that were damaging the ecology of the region. The Baduy, also the Inner Baduy, had been very eagerly planting trees on these obtained locations, she said. Ully Sirgar also wanted to establish an information centre about the Baduy at that place. Not in Cibolégér near the border with Kanékés, as I had suggested to the village head. Further, she told that the Indonesian government had offered the foundation a subsidy, but that she had refused the offer, so that she could stay more independent (A1992-2: 15-16).

During my fieldwork in July 2016 I raised the issue of mediation by NGOs, also triggered by experiences in the months before that will be discussed below. It became clear that the Baduy leaders were not very interested in NGOs

41 See, for instance, https://id.wikipedia.org/wiki/Ully_Sigar_Rusady [last access 16 March 2019.] 
and did not really trust them, certainly not the NGOs that were subsidized by the Indonesian government. Two Baduy leaders that I had interviewed before in 1992 and 2003 expressed their disappointment: in the 1990s the Garuda Nusantara foundation had bought land in Cihandam but that had in no way been helpful in solving the Baduy's shortage of agricultural land. They said that it had only benefitted the people who had established the foundation (A20161: 32,40$)$. According to Suryani ([2020]: chapter 4, section D and chapter 5 , section A-5) in 2017 villagers told him that they thought that Ully Sigar's environmental programme was funded by Christian organizations in the USA. That did not support its trustworthiness.

An important part of the work by the Garuda Nusantara foundation could be described as raising awareness for ecological issues and Intangible Cultural Heritage, like indigenous knowledge systems, as described in the UNESCO 2003 Convention for the Safeguarding of the Intangible Cultural Heritage. This is also reflected in, for instance, the efforts to organize symposia on these issues and the production of a film for the general public in 2016: My Journey Mencari Mata Air (My journey: In search for the well). ${ }^{42}$ Although the Baduy have always been interested in ecological issues and keeping their environment ritually clean, it seemed that they had little understanding for those more general issues raised by the Garuda Nusantara foundation. There seems to be an important information gap between the foundation and the Baduy leaders. ${ }^{43}$

In 2016 my interest in the work of NGOs concerning the Baduy had been raised again when I received a short E mail message from the Gerakan Héjo (Green Movement) foundation ${ }^{44}$ on 10 April 2016, a few months before my planned fieldwork in Kanékés. In this message the director Saladin Belhacel told me that his organisation was 'currently working to put the Baduy ethnic minority people on the мав [Man and the Biosphere Programme] Unesco's list'. The foundation also wanted Baduy music to be listed on one of the lists of the 2003 UNESCO convention. The director wrote that they would 'be honoured' if I would 'accept to join' them.

42 See, for instance, <http://www.tribunnews.com/mpr-ri/2016/o1/27/kerusakan-lingkunganjadi-perhatian-mpr-ri> [last access 16 March 2019.]

43 On the relationship between NGOs and indigenous peoples see also Persoon (1998: 285286). He gives the example of the wWF (World Wildlife Fund) and remarks that '... principles for partnership with indigenous peoples' organizations are utilitarian and conditional.'

44 Between April 2016 and May 2017 their website was http://www.gerakanhejo.or.id/; this site disappeared before April 2019. 
I looked at the website of the NGO Gerakan Héjo and found that in the section on the Baduy they had quoted the words of a song, published in my 2004 article..$^{45}$ I further noted that they presented outdated information on this website. Hence I wrote back to the director that they should improve the information about the Baduy on their website and

If the Yayasan Gerakan Hejo wants to help the Baduy by using international listing, for me it is crucial to know what the Baduy themselves think about this. Personally I am not at all convinced that listing (UNESCO) is a solution to the problematic situation of the Baduy. The main problem is in Indonesia itself: not allowing enough room for minorities. Religion is an important factor in this - see my 2004 article 'Les temptations des ascètes ...' - and the Baduy are exploited by the touristic industry (and many of them get corrupt).

On 23 April 2016 I received new information from the Gerakan Héjo foundation. This also included a copy of the letter of Gerakan Héjo (Chairman Mr Eka Santosa and director of international relations Saladin Belhacel), dated 9 March 2016 to Prof. Dr. T.A. Fauzi Soelaiman of the Permanent Delegation of the Republic of Indonesia to Unesco in Paris. They wrote that the Gerakan Héjo was apparently interested in putting the Baduy area on the World Heritage list of the 1972 UnEsCo Convention Concerning the Protection of the World Cultural and Natural Heritage:

I met the spiritual leader, the Pu'un of Cikatarwana [Cikartawana], who confirmed me that every three Pu'uns from Cibeo, Cike[u]sik and himself, as well as all Jaros are consent to be represented by 'Gerakan Hejo', for to register them on the list of the UNESCO World Heritage.

There were apparently several plans made by the Gerakan Héjo with respect to UNESCO: putting the Baduy area on the World Heritage List, putting the Baduy area on the Man and Biosphere programme and also putting their intangible heritage on a list of the 2003 Convention for the Safeguarding of the Intangible Cultural Heritage.

When I arrived in Kanékés in July 2016, I asked several officials about the activities of the Gerakan Héjo: the village secretary, the secular village head,

45 'Look, I have been wounded for a long time/Which medicine can cure this?/The longer it lasts, the deeper my sorrow/Oh, there are so many temptations!' (Van Zanten 2004: 124; see also the very beginning of Chapter 1 ). 
a member of the Cibéo hamlet council (A2016-1: 40), and also someone close to the puun of Cikartawana. None of these important people had heard about this NGO that was going to 'represent' the Baduy to UnESCO. What was striking in this letter of Gerakan Héjo dated 9 March 2016 was the procedure that was followed: apparently Chairman Eka Santosa met with the puun of Cikartawana and discussed things with him. However, the first people to consult on such matters related to the outside world are not the puun, but, for instance, the secular village head, the jaro tanggungan duabelas and the Kanékés secretary. However, these Baduy officials apparently did not care about the activities of the Gerakan Héjo. It seemed that they were used to such situation. It supported the idea that the Baduy are not really interested in NGOs.

The NGO WAMm BY (Wadah Musyawarah Masyarakat Baduy, Consultative Association of the Baduy Community) was different. It was established by people of Baduy descent who were living outside Kanékés. I do not have many details about the organisation, but the driving force behind this organization seems to have been Kasmin Saelani, a businessman and local politician of Baduy descent. I guess that WАммBY was established in the 1990s (A2003-1: 11) and its office is in Rangkasbitung. The main activity of WАMмBY was to promote Baduy products. In 2016 WAMMBY started to sell Baduy products like woven cloths, honey, bags (koja) and knives (golok) on the Internet. ${ }^{46}$

WAM MBY also supported the Baduy in their fight concerning environmental issues and shortage of agricultural land. According to carik Sapin, WAMM BY was also very much involved in obtaining the status of indigenous community (masyarakat adat) with collective land rights (hak ulayat; A2014-1: 61) for the Baduy, which happened in 2001 (see Section 1.1). Kasmin Saelani has been chairman of WAMMBY for many years, at least until 2015, when he was taken to court and sentenced to a few years imprisonment because of corruption. This corruption case of Kasmin had to do with the local elections for a regent of Rangkasbitung (bupati Lebak) in which Kasmin was the Golkar party's candidate for regent. The corruption case also involved the governor of Banten, Ratu Atut Chosiyah, in Sérang and judge Akil Mochtar of the Constitutional Court. 47

Although he was in prison, the Baduy leaders still showed their respect to Kasmin Saelani. In 2016 I arrived in Kanékés on 1 July, a few days before

46 See http://www.antaranews.com/berita/586411/wammby-promosikan-kerajinan-baduydi-internet. [Last access 22 January 2019.]

47 See, for instance, https://www.merdeka.com/peristiwa/kpk-resmi-jebloskan-dua-tersangkasuap-pilkada-lebak-ke-bui.html. [Last access 22 January 2019.] 
Lebaran/Idul Fitri (starting Tuesday evening 5 July 2016). In the evening of Thursday 7 July secular village head Saijah headed a party of Baduy who travelled by car to Bandung to visit Kasmin in the Suka Miskin prison on this occasion of the Lebaran feast. My assistant Mumu was asked to be the eighth person of the party, because he knew how to find the Suka Miskin prison in eastern Bandung. Initially I had also been asked whether I would join this party, and the former secular village head Asrab had said that I should certainly go. However, I had expressed my concern that as a foreigner who did not know Kasmin personally it would be better for everyone if I would not go into the prison building (A2016-1: 29-31, 33) and subsequently jaro Saijah also thought that it would be best if I stayed in Kanékés.

An organization like WАмм BY is apparently trusted by the Baduy leaders, whereas other NGOs are not entirely trusted. The kinship relations between the people involved are important. Migrated Baduy regularly attend marriages and circumcisions taking place in their family in Kanékés. It seems to me that a further study of the NG Os could shed more light on the policies of the Baduy rulers towards the outside world.

\subsection{Weaving, Clothes and Production of Textiles for Sale}

As mentioned above cloths and clothing are very important for the Baduy community. Since about 2000 there has been a shift in the use of colours used for the woven cloths. Before the major colours were blackish-blue, white and dark-red, and gradually colours like light-green and yellow were added, I presume mainly for trying to sell it to tourists and the outside market (see Figure 20 below).

Already in 1822 Blume mentioned that the Baduy have to make their own clothes. The raw cotton needed for the weaving of the cloths was obtained from 'small markets' around Kanékés. According to Blume the raw cotton and other products from outside (like salt, silver ear rings and bracelets) were exchanged for rice from Kanékés. The 'Girang puun' was responsible for these transactions and now and then the puun visited the markets with some elders to exchange rice for cotton (Blume 1993 [1822]: 35). Nowadays it is unthinkable that a puun would go to a market outside Kanékés: he is not allowed to leave the tangtu area. ${ }^{48}$ Moreover, the Baduy are allowed to buy rice from

48 As discussed at the end of Section 2.1 and below in Section 3.2, it may be that Blume meant a former puun, who had to resign because his wife died, but who still kept the honorific title girang puun. In that case, as an ordinary Inner Baduy, he would be allowed to leave Kanékés. 
outside Kanékés, but they are not allowed to sell the rice that was grown in Kanékés. ${ }^{49}$

The cotton is still bought from outside Kanékés, because the Baduy are not allowed to cultivate the cotton plant. Reiss (2012: 58) mentioned that she visited Gunung Buleud and surrounding villages, a few kilometres south of Kanékés, in September 2011. She was informed that tangtu people had come to Sukamana village in that area since the 1940s to buy raw cotton, spun threads and white loosely-woven cloth (boéh rarang) only used for ritual purposes such as wrapping a corpse before burying. Although cotton is still bought outside Kanékés, like two hundred years ago, other things have changed considerably since Blume's report. For instance, since the 1970s the use of industrially produced yarn has increased (Bakels 1991: 22; 1993: 350). Reiss (2012: 54-55) described a visit in November 2010 to a small weaving factory in Majalaya, about $30 \mathrm{~km}$ southeast of Bandung, where since the beginning of the 21st century sarongs for the Outer Baduy are produced, using industrially produced yarns and chemical dyes.

Both the Inner and the Outer Baduy men and women can be recognized because of the special clothes they wear. The basic colours are white and black/ blue. However, for the outsider there is a puzzling number of different motives. Inner Baduy only wear cloth woven in Kanékés (see also Bakels 1991: 17; Reiss 2012: 74-78). There are many weavers in Kanékés: for 2012 Reiss (2012: 52 ) listed 21 weavers in the three Inner Baduy hamlets and 417 weavers in 14 Outer Baduy hamlets. Most of the weavers are women and girls, but also some men and boys weave (see Figure 21). In current practice the daily clothes for Outer Baduy men and women are mostly produced outside Kanékés: printed dark blue on bright blue batik patterns and plain black cloth is used for these purposes. In 2015 the blue-black printed batik (mérong, see Figure 16) used by Outer Baduy for the men's head cloth and women's sarong and produced outside Kanékés, was patented as Batik Lebak with twelve motifs (Van Zanten 2017: 92-93)..$^{50}$ This increase in wearing the printed batik and other commercial cloth from outside Kanékés has undoubtedly partly been accelerated by the fact that many of the woven cloths are sold to tourists. However, on special occasions the Outer Baduy tend to wear clothes made from cloth that has been woven inside Kanékés.

As already mentioned in Section 1.1, the most important clothing difference between Inner and Outer Baduy men is that in daily life the Outer Baduy men

49 This fact that in current practice the people of Kanékés will never sell the rice grown in their village was, for instance, confirmed to me by the secular village head Daénah in December 2013. Also in the Kasepuhan Ciptagelar, about 40 km southeast of Kanékés, the farmers are not allowed to sell rice from their own fields (Budi 2015: 111). 
have a head cloth with blackish-blue patterns of printed batik (mérong) and mostly short black trousers; the Inner Baduy men wear a white head cloth and never trousers, but a dark blackish-blue woven sarong with a striped pattern. This sarong is kept in place by a waist-belt (sabuk) that is entirely white. The daily dress of Outer Baduy women is mostly a printed batik sarong, in dark blue on a bright blue background, and a dark blue or dark brown long-sleeved blouse, or just a T-shirt. Outer Baduy women may also wear a dark blue woven sarong. Inner Baduy women wear a black-woven sarong and a white or black long-sleeved shirt. In Figure 19 on the upper row, from left to right are:

1. Ordinary sarong for Outer Baduy women (samping poléng kacang hérang);

2. Shoulder cloth for Outer Baduy women (lamak suat samata);

3. Stole for Outer Baduy women (lamak suat songkét).

On the lower row, from left to right are:

4. Sarong for Inner Baduy men (samping aros);

5. Waist-belt for tightening a ceremonial sarong (sabuk adu mancung);

6. Ceremonial sarong for Outer Baduy men (samping poléng paulunas).

See for more information on clothing and the symbolic meaning of the colours Bakels (1991; 1993) and Reiss (2012: 74-87).

In the past clothes were also made from the leaves of a particular kind of rattan (pélah; see Meinsma 1869: 338). Bakels (1991: 17) mentions that this was common until the end of the 19th century, and that it only survived in Cikeusik. According to Reiss (2012: 70) the Baduy 'revived the tradition of weaving cloth from the young leaves of a rattan plant growing naturally in their environment' during the difficult years of the Japanese occupation (1942-1945). However, pélah weaving is now dying out, because it is a time-consuming activity, as becomes clear from Reiss's description. She adds that currently there are only five pélah weavers left in the tangtu area.

\subsection{Production of Other Goods}

Agriculture, and in particular rice growing, remains the major source of living for Baduy families. Rice is not sold but stored in the rice barns (leuit) for own use, sometimes for many years. Fruit and vegetables are also produced for one's own use, but much fruit like bananas, kadu (durian), jackfruit (nangka), rambutan and different kinds of $d u k u,{ }^{51}$ is mainly produced for the market.

51 Kadu/durian: durio zibethinus; rambutan: nephelium lappaceum; duku: lansium domesticum (Teeuw 199o, Stevens and Schmidgall-Tellings 2010.) 


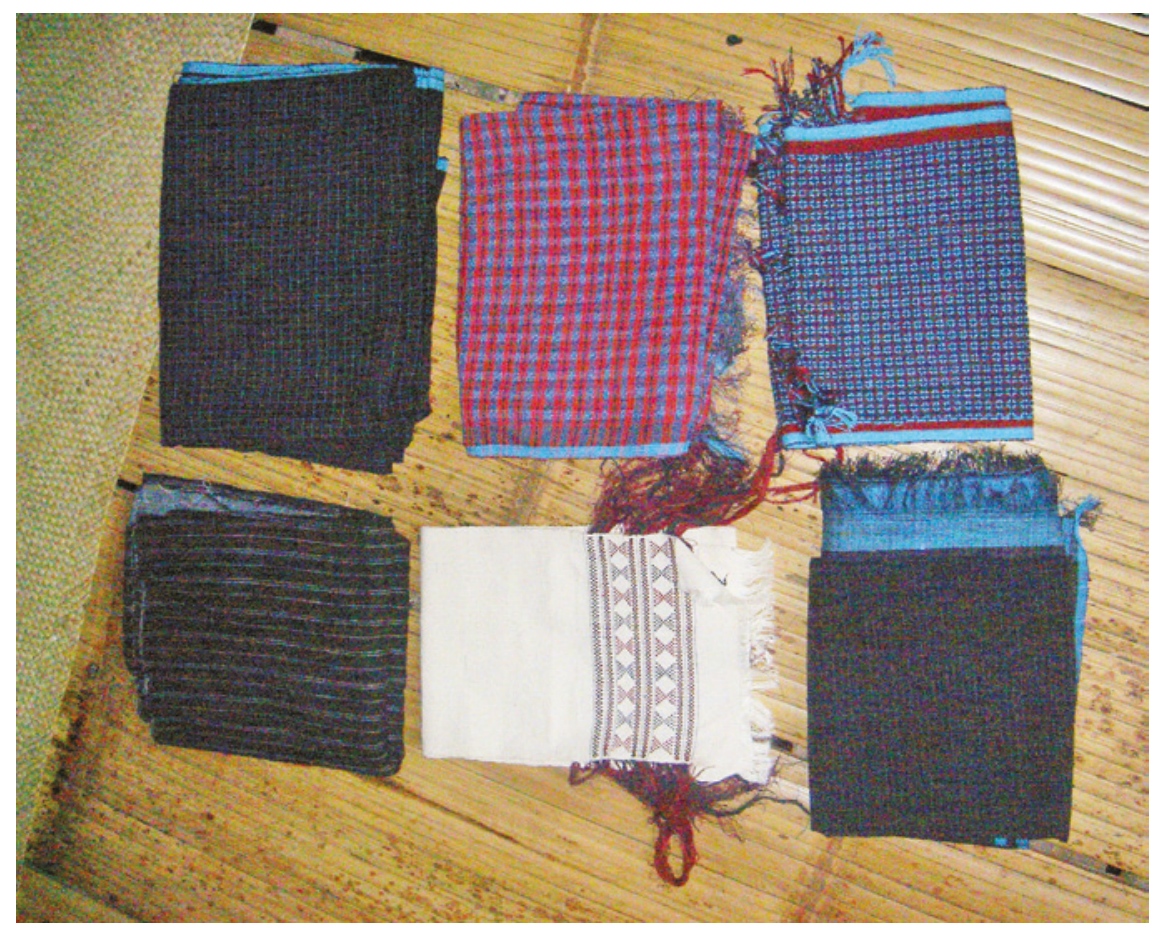

FIGURE 19 A few types of cloth woven in Gajeboh and sold by Ambu Icot, wife of Aki Nasinah, 24 March 2003

As discussed in Section 2.6, weaving has become an increasingly important source of income; this can also be seen from the large number of about 440 weavers in Kanékés in 2012 (Reiss 2012: 52 ). However, there are more products that are sold to non-Baduy visitors, or on the markets outside Kanékés. Baduy men travel as far as Bandung or Jakarta to sell the knives, honey and hand bags. This section will briefly discuss the making of palm sugar and knives below.

\subsubsection{Palm Sugar (gula kawung)}

Baduy buy their salt on the markets outside Kanékés, but they make sugar themselves from the juice of the sugar palm (kawung, Ind. arén). The juice is collected in bamboo containers of $80-90 \mathrm{~cm}$ long that are tied to the palm tree. The sugar juice is collected twice a day. In the morning the harvest is larger than in the evening. The juice is then put into a large and wide saucepan and boiled for about three days, while stirring regularly (see Figure 22c; A1979, 16 July 1979)

The different stages of the fluid when making sugar are called: palm juice (lahang), boiling palm juice, just before it starts to thicken (wédang) to thicker sugary fluid (gula ngora, 'young sugar') to very thick fluid that is put in forms 


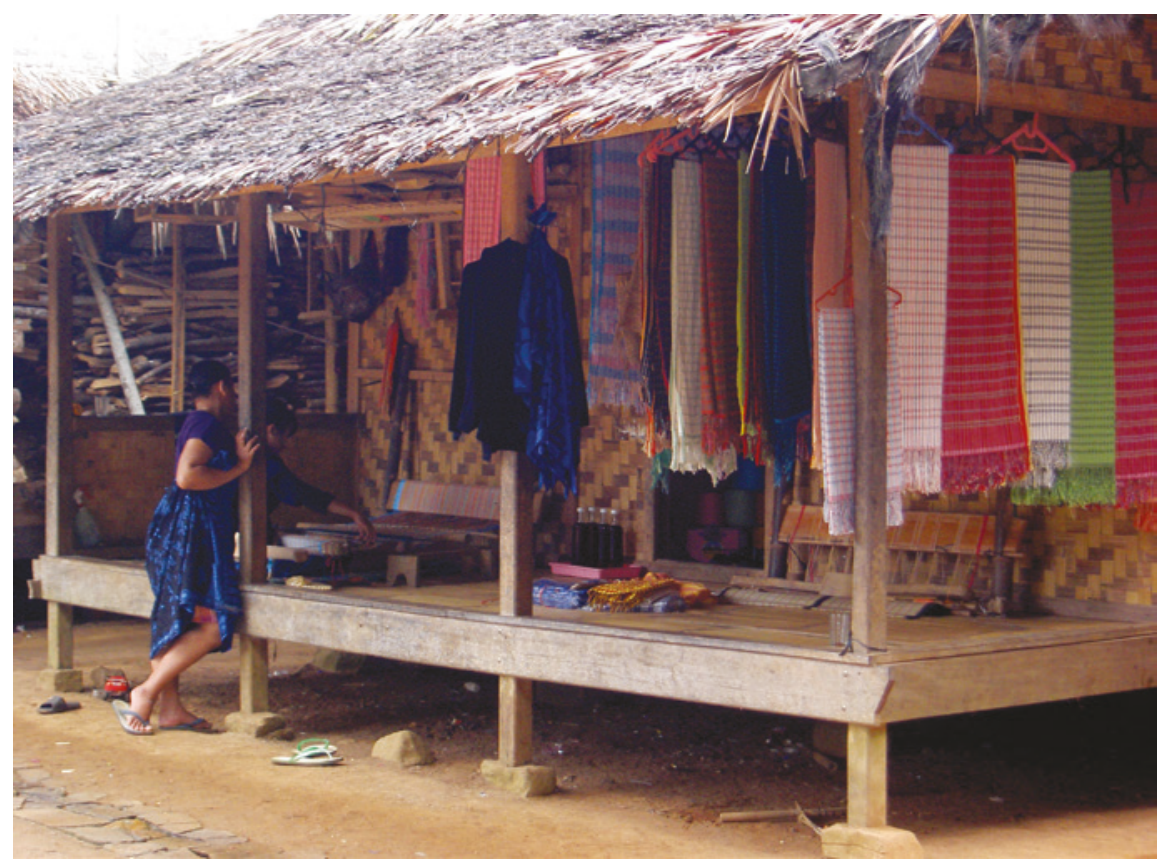

FIGURE 20 Outer Baduy woman in sarong of black-blue printed batik (mérong) and blue T-shirt next to cloths in modern colours for tourists. House of Arwan in Kaduketug 1, 11 December 2013

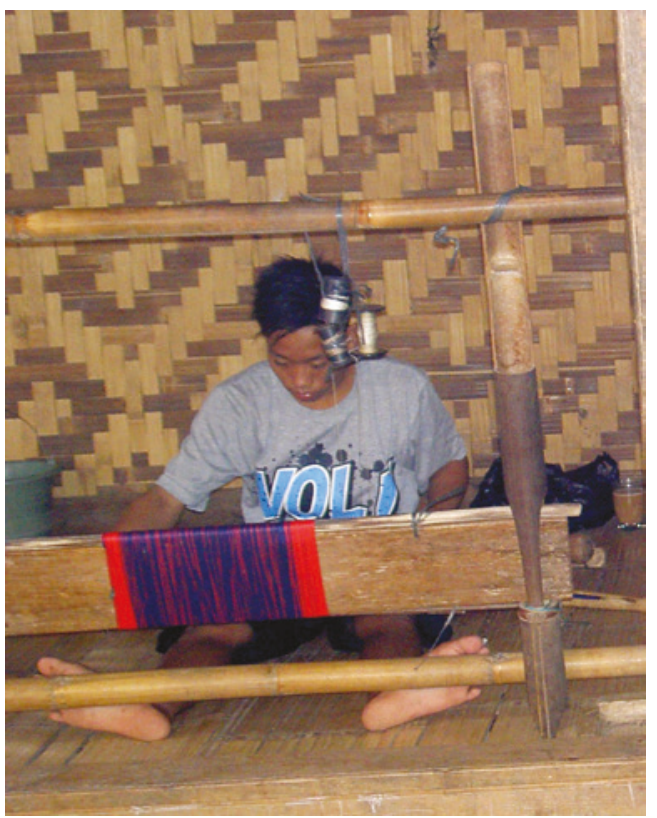

FIGURE 21 Baduy boy weaving on a veranda in Kaduketug 1, 11 December 2013 
to harden (gula kolot, 'old sugar'). The moulds in which the thick sugar fluid is poured produce half balls of sugar (see Figure 22). When sold, these are tied together in pairs (hulu) and in July 1979 per pair sold for 100-125 Rupiah on the market (€ 0.14-0.17, US\$ 0.16-0.20); in July 2016 this was 6000-100oo Rupiah (€ 0.41-0.69, Us\$ 0.46-0.76; see A2016-2: 13, 30). The highest prices are usually obtained in the fasting period (Ramadan), and especially at the end (Lebaran).

In Figure 22 the different pictures show on the left side from top to bottom: a container for the juice (22a), the moulds for the sugar (22b) and the finished half-balls of palm sugar (22c). On the upper-right side is the palm sugar juice heated in a wide saucepan (22d). The black-and-white picture below-right shows two men of which one is carrying a bunch of sugar-halves tied together in pairs and that is carried to a market outside Kanékés (22e).

In 2016 I witnessed one round of making palm sugar in Kaduketug Gedé that took three days. At the end the containers for the juice (lahang) were cleaned by putting a piece of bamboo in the fire; when this started to smoulder, it was put in the bamboo juice container for $5^{-10}$ minutes. In this round of three days there were about 6o sugar halves produced, or about 3 o pairs (hulu).

The juice of the sugar palm is also drunk when fresh. If left fermenting for one day it has some alcohol in it and is called tuak; if left fermenting for two days, it is called wayu (A2016-2: 12-13). According to Danasasmita and Djatisunda (1986: 51) and Garna (1988: 91), the Inner Baduy are allowed to drink the wayu, but they are not allowed to make the palm sugar. They have to buy the palm sugar from the Outer Baduy.

\subsubsection{Knives}

Baduy smiths make several types of knives and agricultural utensils; see Figure 23:

23a: golok for Inner Baduy (top-left);

23b: golok for Outer Baduy (top-right);

23c: golok for Inner Baduy (middle-left);

23d: knife for harvesting rice (étém; Ind. ani-ani) and small hoe or sickle to weed the rice field (koréd) on the middle-right;

23e: Below is Aki Daénah (L) in the house of his son, jaro pamaréntah Daénah.

He has an Inner Baduy golok in his hand and two smaller knives (péso)

before him on the ground. He wanted to sell those knives on the market outside Kanékés. On the right my research assistant Mumu. Kaduketug 1, 13 December 2013 .

Most of these products are produced for local use. However, especially the golok, a large knife for daily use by Baduy men and called bedog in other parts of Sunda, is also sold to tourists visiting Kanékés and in large cities like 


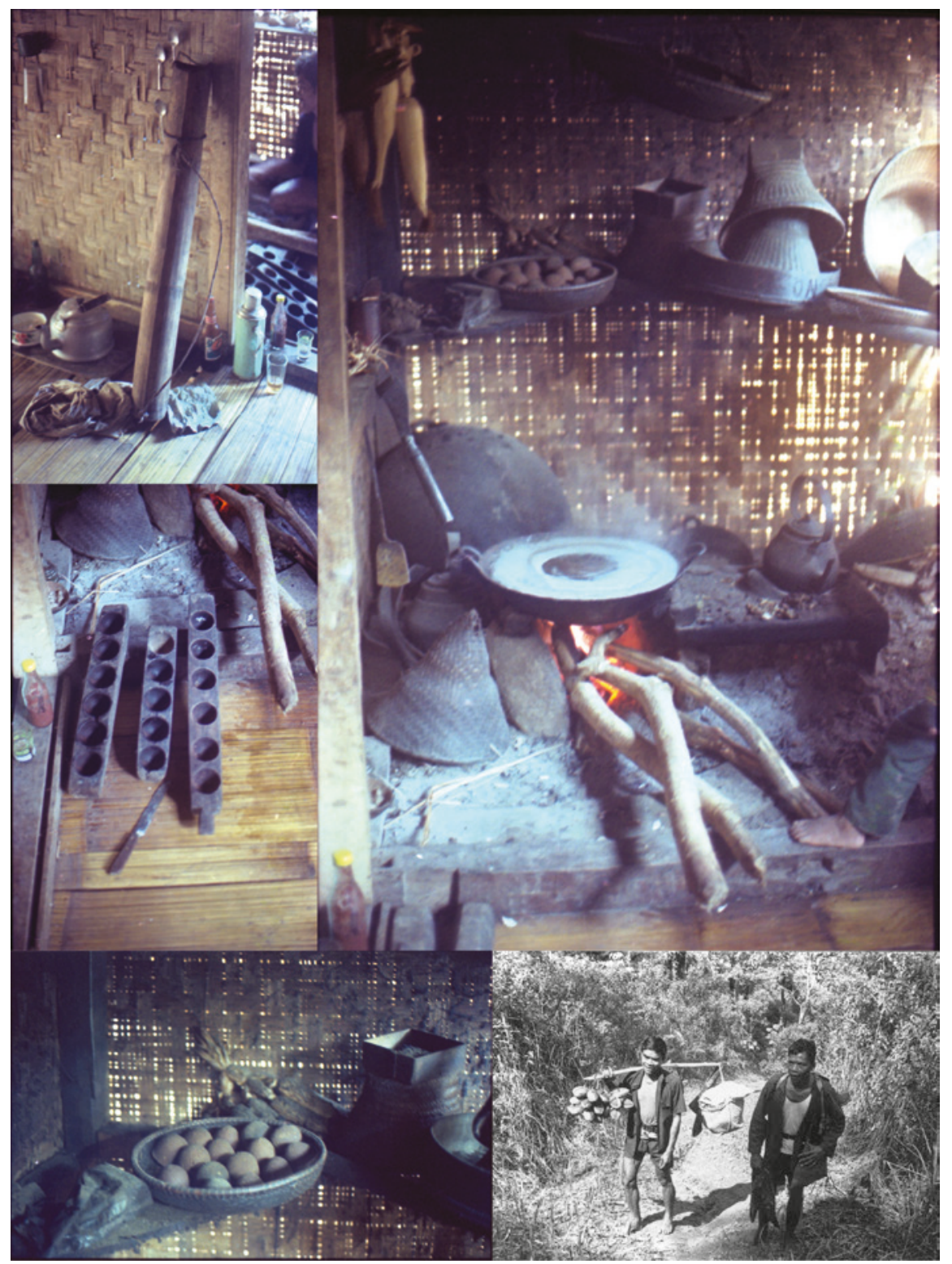

FIGURE 22 The production of palm sugar from juice (lahang) to half balls of sugar. Kadujangkung, 1979 and 1976 
Bandung and Jakarta. ${ }^{52}$ The grip and sheath of an Inner Baduy knife are always made of light-coloured wood (sungké 'white' wood) and may only be made of vegetable materials (A2003-1: 30). Hence, the small strips around the sheath of the Inner Baduy golok are made of vegetable products. The grip and sheath of Outer Baduy knives are made of dark wood and often contain animal products, like the white bone and twined pieces of buffalo horn (tanduk kebo) wound around the example in the top-right of Figure $23 .{ }^{53}$

Inner Baduy knives mostly have sulangkar patterns (also called pamor) hammered into the blade by using different pieces of steel; see Figure 23. It seems that the blades of Outer Baduy knives rarely show the sulangkar patterns. On 24 March 2003 I bought an Inner Baduy golok knife with sulangkar patterns for Rp 150.00o (about € 15.30, Us\$ 16.65; A2003-1: 30). The smaller knife (péso) lying left on the ground in Figure 23d in front of Aki Daénah also contains sulangkar patterns and I bought it for Rp 100.000 (ca €6.40, US\$ 8.60) on 13 December 2013 .

It seems that the number of Baduy smiths have decreased in the last decennia (A2014-1: 6o), however, I have no details about this. In 1992 I was told by Usman, living in Cipangembar since 1978, that a Baduy smith may only work on a golok knife on special days of the week and that he can only use a limited number of blows with his hammer on one day (Usman, A1992-1: 32). See for more information on the mythical ancestors of the Sundanese smiths (Panday Domas: 'the 800 smiths'), going back to the Pajajaran kingdom, the article by Linder (1985). I will not go into these details in this book.

Ending this section, in Table 3 I present some of the prices of products that Baduy sell to visitors and people in the large cities: cloths and clothing, musical instruments and utensils. These prices are only rough indications, as, for instance, the price of a golok knife very much depends on the quality of the sulangkar patterns of the blade and the decorations on the grip and the sheath.

$5^{2}$ See also Section 2.5, where I mentioned that the NGO WAmmBY started to sell Baduy products, including golok knives, via the Internet in 2016.

53 Although buffalos are not allowed in Kanékés, the Outer Baduy may use buffalo bones and horns for producing the grips and sheaths of knives. The Outer Baduy are also allowed to eat the meat of a buffalo. In the evening of 5 July 2016, the end of the fasting month and the start of Idul Fitri (or Lebaran) and in this year coinciding with the first day of the Baduy month Sapar, jaro pamaréntah Saijah and his wife had prepared buffalo meat, obtained from outside Kanékés, that I and Mumu were offered to eat with them and the family in their kitchen/living room. The meat was prepared as a kind of rendang (pieces of meat cooked with spices and coconut milk until dry) and saté (pieces of meat roasted on a wooden skewer). 


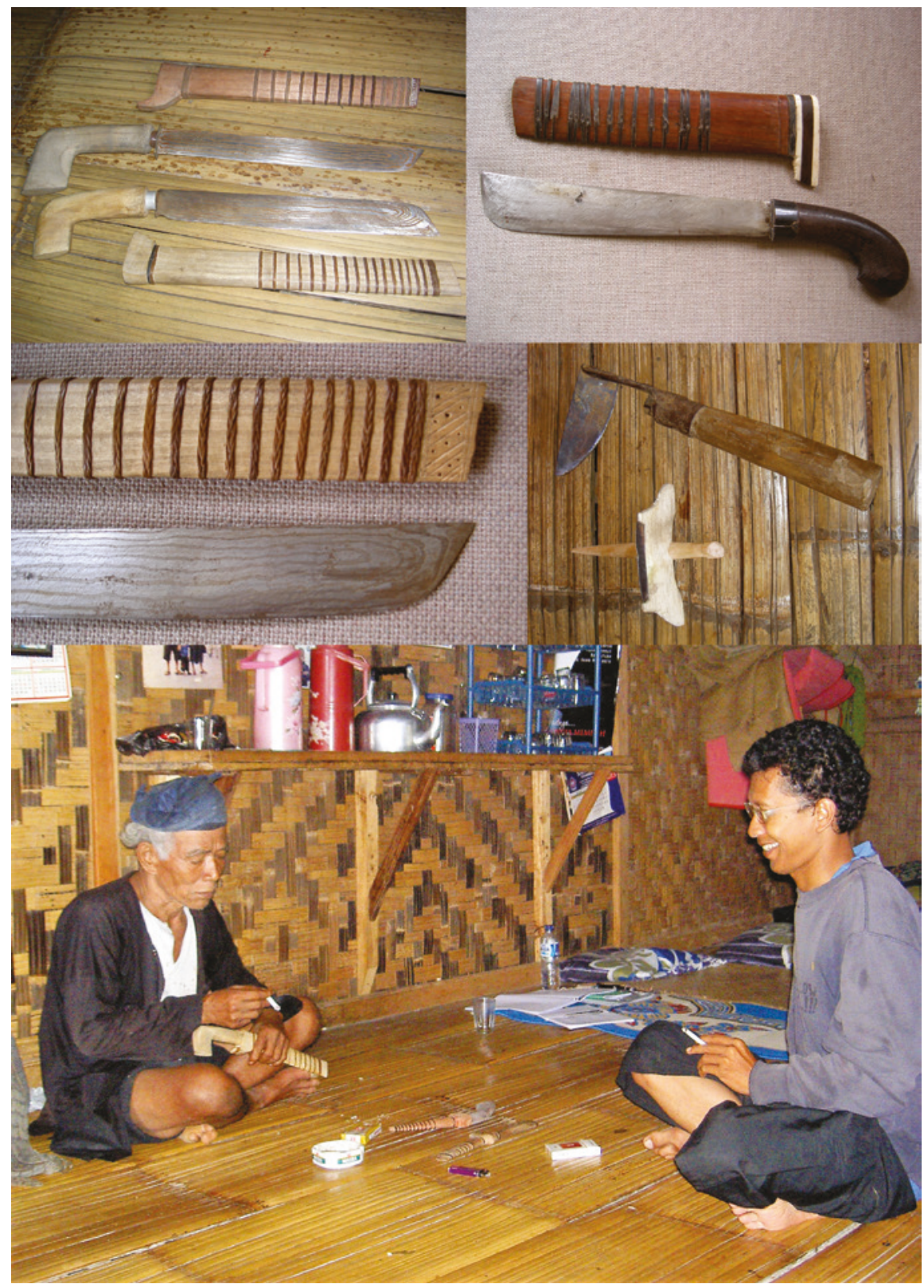

FIGURE 23 Knives and agricultural utensils made by Baduy smiths. Below Aki Daénah with knives in the house of his son, the village head, talking to my assistant Mumu. Kaduketug 1, 13 December 2013 
TABLE 3 Prices of some goods sold by the Baduy 1976-2016

These prices are only rough figures. I bought most of these goods without negotiating about the price. The Euro $(€)$ replaced the Dutch guilder (Dfl) on 1 January 2002 with the exchange rate of Dfl 2.2 to $€_{1}$. In this table all prices of goods before 2002 are presented in Euro and with this fixed rate to the Dutch guilder.

\begin{tabular}{|c|c|c|c|c|c|}
\hline Item & date & Rupiah & us\$ & $€$ & reference \\
\hline \multicolumn{6}{|l|}{ Cloths and clothes } \\
\hline $\begin{array}{l}\text { Poléng kacang hérang } \\
\text { sarong Outer B }\end{array}$ & $\begin{array}{l}24 \mathrm{Ma} . \\
2003\end{array}$ & 40000 & 4.44 & 4.08 & A2003-1: 30 \\
\hline $\begin{array}{l}\text { Poléng paulunas sarong } \\
\text { Outer B }\end{array}$ & $\begin{array}{l}24 \mathrm{Ma} . \\
2003\end{array}$ & 40000 & 4.44 & 4.08 & A2003-1: 30 \\
\hline \multirow[t]{2}{*}{$\begin{array}{l}\text { Samping aros daily } \\
\text { sarong Inner B }\end{array}$} & $\begin{array}{l}8 \text { Nov. } \\
1992\end{array}$ & 6 ooo & 3.06 & 2.20 & A1992-2: 66 \\
\hline & $\begin{array}{l}24 \mathrm{Ma} . \\
2003\end{array}$ & 35 ००० & 3.89 & 3.57 & A2003-1: 30 \\
\hline $\begin{array}{l}\text { Samping poléng sarong } \\
\text { Outer B }\end{array}$ & $\begin{array}{l}21 \text { July } \\
2016\end{array}$ & 150000 & 11.40 & 10.50 & A2016-2: 14 \\
\hline $\begin{array}{l}\text { Sabuk adu mancing } \\
\text { cloth for fastening } \\
\text { poléng paulunas Outer } \\
\text { B }\end{array}$ & $\begin{array}{l}24 \text { Ma. } \\
2003\end{array}$ & 20000 & 2.22 & 2.04 & A2003-1: 30 \\
\hline $\begin{array}{l}\text { Lamak suat songkét, } \\
\text { shoulder cloth for } \\
\text { Outer B women }\end{array}$ & $\begin{array}{l}24 \mathrm{Ma} . \\
2003\end{array}$ & 30000 & $3 \cdot 33$ & 3.06 & A2003-1: 30 \\
\hline $\begin{array}{l}\text { Lamak suat samata, } \\
\text { broad shoulder cloth } \\
\text { for Outer B women }\end{array}$ & $\begin{array}{l}24 \mathrm{Ma} . \\
2003\end{array}$ & 35 ००० & 3.89 & 3.57 & A2003-1: 30 \\
\hline \multirow[t]{2}{*}{$\begin{array}{l}\text { Men's black jacket/ } \\
\text { shirt Outer B }\end{array}$} & $\begin{array}{l}7 \text { April } \\
2003\end{array}$ & 25000 & 2.78 & 2.55 & A2003-1: 72 \\
\hline & $\begin{array}{l}\text { 6 June } \\
2014\end{array}$ & 100 0o० & 8.40 & 6.20 & A2014-1: 6o \\
\hline $\begin{array}{l}\text { Men's black trousers } \\
\text { Outer B }\end{array}$ & $\begin{array}{l}8 \text { Nov. } \\
1992\end{array}$ & 4000 & 2.04 & 1.47 & A1992-2: 66 \\
\hline $\begin{array}{l}\text { Men's head cloth of } \\
\text { mérong Outer B }\end{array}$ & $\begin{array}{l}7 \text { April } \\
2003\end{array}$ & 17000 & 1.89 & 1.73 & A2003-1: 72 \\
\hline
\end{tabular}


TABLE 3 Prices of some goods sold by the Baduy 1976-2016 (cont.)

\begin{tabular}{|c|c|c|c|c|c|}
\hline Item & date & Rupiah & Us\$ & $€$ & reference \\
\hline $\begin{array}{l}\text { Men's shirt of mérong } \\
\text { batik - tourists } \\
\text { Utensils }\end{array}$ & $\begin{array}{l}18 \text { July } \\
2016\end{array}$ & 150.000 & 11.40 & 10.35 & - \\
\hline \multirow[t]{2}{*}{$\begin{array}{l}\text { Golok knife with } \\
\text { sulangkar, Inner B }\end{array}$} & $\begin{array}{l}17 \text { Oct. } \\
1992\end{array}$ & 25000 & 12.75 & 9.20 & A1992-1: 47 \\
\hline & $\begin{array}{l}24 \\
\text { Mar } \\
2003\end{array}$ & 150000 & 16.65 & $15 \cdot 30$ & A2003-1: 30 \\
\hline $\begin{array}{l}\text { Golok without } \\
\text { sulangkar, Outer B }\end{array}$ & $\begin{array}{l}17 \text { Oct. } \\
1992\end{array}$ & 12500 & 6.38 & 4.60 & A1992-1: 47 \\
\hline $\begin{array}{l}\text { Golok with sulangkar, } \\
\text { Outer B }\end{array}$ & $\begin{array}{l}6 \text { Nov. } \\
1992\end{array}$ & 30000 & $15 \cdot 3$ & 11.04 & A1992-2: 18 \\
\hline $\begin{array}{l}\text { Péso (knife) with } \\
\text { sulangkar, Inner B }\end{array}$ & $\begin{array}{l}13 \\
\text { Dec. } \\
2013\end{array}$ & 100000 & 8.60 & 6.40 & A2013: 42 \\
\hline Koja bag & $\begin{array}{l}24 \mathrm{Ma} . \\
2003\end{array}$ & 35000 & 3.89 & $3 \cdot 57$ & A2003-1: 73 \\
\hline \multicolumn{6}{|l|}{ Musical instruments } \\
\hline Kacapi pantun zither & $\begin{array}{l}24 \mathrm{Ma} . \\
2003\end{array}$ & 150000 & 16.65 & $15 \cdot 30$ & A2003-1: 73 \\
\hline Elét flute & $\begin{array}{l}24 \mathrm{Ma} . \\
2003\end{array}$ & 30000 & $3 \cdot 33$ & 3.06 & A2003-1: 73 \\
\hline Suling kumbang flute & $\begin{array}{l}\text { 5 June } \\
2014\end{array}$ & 100000 & 8.40 & 6.20 & A2014-1: 57 \\
\hline Tarawélét flute & $\begin{array}{l}\text { 5 June } \\
2014\end{array}$ & 100 o०o & 8.40 & 6.20 & A2014-1: 57 \\
\hline Karinding Jew's harp & $\begin{array}{l}6 \\
\text { April } \\
2003\end{array}$ & 25000 & 2.78 & 2.55 & \\
\hline \multirow[t]{3}{*}{$\begin{array}{l}\text { Angklung set, including } \\
\text { 2(?) drums }\end{array}$} & $\begin{array}{l}2 \text { Sept. } \\
1976\end{array}$ & 22500 & 54.00 & $5^{0.36}$ & A1976-7:48 \\
\hline & $\begin{array}{l}15 \text { Oct. } \\
1992\end{array}$ & 275 ○०० & 136.00 & 105.00 & A1992-1:39 \\
\hline & $\begin{array}{l}16 \text { July } \\
2016\end{array}$ & $\begin{array}{l}2000 \\
000\end{array}$ & $15^{2.00}$ & 138.00 & A2016-1: 65 \\
\hline
\end{tabular}


TABLE 3 Prices of some goods sold by the Baduy 1976-2016 (cont.)

\begin{tabular}{|c|c|c|c|c|c|}
\hline Item & date & Rupiah & Us\$ & $€$ & reference \\
\hline Gambang xylophone & $\begin{array}{l}2 \text { Sept. } \\
1976\end{array}$ & 8 о०० & 19.28 & $17 \cdot 90$ & A1976-7:48 \\
\hline $\begin{array}{l}\text { Calung 'xylophone' } \\
\text { from bamboo }\end{array}$ & $\begin{array}{l}2 \text { Sept. } \\
1976\end{array}$ & 8 о०० & 19.28 & $17 \cdot 90$ & A1976-7:48 \\
\hline Keromong (gamelan) & $\begin{array}{l}\text { April } \\
1976\end{array}$ & 500 o०o & 1205.00 & 1119.00 & Section $5 \cdot 4$ \\
\hline $\begin{array}{l}\text { Rendo 2-string bowed } \\
\text { lute }\end{array}$ & $\begin{array}{l}26 \text { July } \\
1976\end{array}$ & 5 ००० & 12.05 & 11.19 & A1976a: 81 \\
\hline \multirow{3}{*}{$\begin{array}{l}\text { Agricultural products } \\
\text { Palm sugar (gula } \\
\text { kawung): two halves } \\
\text { (hulu) }\end{array}$} & & & & & \\
\hline & $\begin{array}{l}16 \text { July } \\
1979\end{array}$ & $100-125$ & $0.16-0.20$ & $0.14-0.17$ & A1979: $1 b$ \\
\hline & $\begin{array}{l}24 \\
\text { Oct. } \\
1992 \\
21 \text { July } \\
2016\end{array}$ & $\begin{array}{l}\text { 6ooo-10 } \\
\text { ooo }\end{array}$ & $0.46-0.76$ & $0.11-0.13$ & $\begin{array}{l}\text { A2016- } \\
2: 13,20\end{array}$ \\
\hline $\begin{array}{l}\text { Petai beans, } 100 \\
\text { sheaths }\end{array}$ & $\begin{array}{l}25 \text { Ma. } \\
2003\end{array}$ & 100000 & 11.10 & 10.2 & A2003-1: 36 \\
\hline
\end{tabular}

